\title{
Review \\ When the Blood Hits Your Brain: The Neurotoxicity of Extravasated Blood
}

\author{
Jesse A. Stokum ${ }^{1, *,+}$, Gregory J. Cannarsa ${ }^{1,+}{ }^{\mathbb{D}}$, Aaron P. Wessell ${ }^{1}$, Phelan Shea ${ }^{1}$, Nicole Wenger ${ }^{1}$ \\ and J. Marc Simard 1,2 \\ 1 Department of Neurosurgery, University of Maryland School of Medicine, Baltimore, MD 21201, USA; \\ gcannarsa@som.umaryland.edu (G.J.C.); awessell@som.umaryland.edu (A.P.W.); \\ pshea@som.umaryland.edu (P.S.); NMWenger@som.umaryland.edu (N.W.); \\ MSimard@som.umaryland.edu (J.M.S.) \\ 2 Departments of Pathology and Physiology, University of Maryland School of Medicine, \\ Baltimore, MD 21201, USA \\ * Correspondence: Jstokum@som.umaryland.edu; Tel.: +1-410-328-6034 \\ + Denotes equal contribution.
}

Citation: Stokum, J.A.; Cannarsa, G.J.; Wessell, A.P.; Shea, P.; Wenger, N.; Simard, J.M. When the Blood Hits Your Brain: The Neurotoxicity of Extravasated Blood. Int. J. Mol. Sci. 2021, 22, 5132. https://doi.org/ $10.3390 /$ ijms 22105132

Academic Editors: József Balla and Anuska V. Andjelkovic

Received: 4 March 2021

Accepted: 6 May 2021

Published: 12 May 2021

Publisher's Note: MDPI stays neutral with regard to jurisdictional claims in published maps and institutional affiliations.

Copyright: (c) 2021 by the authors. Licensee MDPI, Basel, Switzerland. This article is an open access article distributed under the terms and conditions of the Creative Commons Attribution (CC BY) license (https:/ / creativecommons.org/licenses/by/ $4.0 /)$.
Abstract: Hemorrhage in the central nervous system (CNS), including intracerebral hemorrhage (ICH), intraventricular hemorrhage (IVH), and aneurysmal subarachnoid hemorrhage (aSAH), remains highly morbid. Trials of medical management for these conditions over recent decades have been largely unsuccessful in improving outcome and reducing mortality. Beyond its role in creating mass effect, the presence of extravasated blood in patients with CNS hemorrhage is generally overlooked. Since trials of surgical intervention to remove CNS hemorrhage have been generally unsuccessful, the potent neurotoxicity of blood is generally viewed as a basic scientific curiosity rather than a clinically meaningful factor. In this review, we evaluate the direct role of blood as a neurotoxin and its subsequent clinical relevance. We first describe the molecular mechanisms of blood neurotoxicity. We then evaluate the clinical literature that directly relates to the evacuation of CNS hemorrhage. We posit that the efficacy of clot removal is a critical factor in outcome following surgical intervention. Future interventions for CNS hemorrhage should be guided by the principle that blood is exquisitely toxic to the brain.

Keywords: intracerebral hemorrhage; aneurysmal subarachnoid hemorrhage; neurotoxicity of blood; evacuation of CNS hemorrhage

\section{Introduction}

Acute CNS hemorrhage, including intracerebral hemorrhage (ICH), intraventricular hemorrhage (IVH), subarachnoid hemorrhage (SAH), subdural hematoma (SDH), and traumatic contusion, comprises a large portion of the modern neurosurgical case load. While neurosurgical techniques have greatly expanded in recent decades, these diseases still leave most patients dead or highly dependent.

\subsection{Intracerebral and Intraventricular Hemorrhage}

ICH and IVH, which occur in $\sim 45 \%$ cases of ICH [1], are major causes of morbidity and mortality worldwide. ICH comprises $10-20 \%$ of all strokes, with an incidence that ranges up to 200 people per 100,000 person-years [2,3]. New ICH cases have risen by nearly 50\% between 1990 and 2010 [4]. Mortality after ICH is 40\% at 1 month and $50 \%$ at 1 year [3]. ICH is highly morbid, with only $12-39 \%$ of patients achieving functional independence after 1 year [3]. Due to this morbidity and mortality, ICH is a very costly disease, with one Canadian study of 987 patients showing an average discharge cost of USD 10,544, and a maximum cost of USD 265,470 [5].

Efforts to improve ICH outcomes through changes in medical management have been unsuccessful. Intensive BP control (INTERACT-2, ATACH-2), administration of platelets 
(PATCH), recombinant factor VIIa (FAST), and tranexamic acid (TICH-2) have all failed to show substantial improvements [6-10].

In $\mathrm{ICH}$, hematoma volume is the strongest predictor of death and function outcome at 1 month [11-14]. Thus, the major causative factor in the failure of the aforementioned trials may be the toxicity of the intracerebral blood.

\subsection{Aneurysmal Subarachnoid Hemorrhage}

Aneurysmal subarachnoid hemorrhage (aSAH) accounts for $\sim 5-10 \%$ of all strokes in the US and has an admission rate of approximately 10 people per 100,000 personyears $[15,16]$. Aneurysm rupture accounts for approximately $\sim 80 \%$ of spontaneous subarachnoid hemorrhage cases [17]. Like ICH, aSAH is highly morbid and mortal. Patients with aSAH suffer from a $\sim 8-66 \%$ case mortality $[18,19]$. Approximately $25 \%$ of survivors are unable to return to functional independence. Furthermore, only $62 \%$ of survivors can return to any form of work, and only 33\% are able to return to their previous job [20]. Hospitalization after aSAH is often long, with an average length of stay of $\sim 20$ days, and often expensive, with mean hospital charges of USD 170,000 [21]. In aSAH, both the initial clot volume and rate of clot clearance predict delayed cerebral ischemia, mortality, and severe disability at 3 months [22-24].

\subsection{Extravasated Blood: More Than Just a Mass Lesion}

Given the impact of extravasated blood, it is surprising that in many cases of intracranial hemorrhage, the extravasated blood is left in place for the neuroparenchyma to degrade and reabsorb. One US study reported that only $7 \%$ of all ICH patients were treated with surgical evacuation [25]. The bias against evacuation can be traced to several clinical trials that have yielded results that argue against routine evacuation of ICH. As a result, blood is often viewed simply as a cause of mass effect, and the decision to evacuate is made accordingly. In the present article, we posit that blood, rather than being merely a mass lesion, is exquisitely neurotoxic to the CNS. We first show that blood is composed of multiple, deleterious neurotoxins. Next, we explore the clinical evidence that supports the evacuation and clearance of CNS hemorrhage, and hypothesize why prior clinical trials have failed to show efficacy for clot evacuation.

\section{Blood Harbors Numerous Neurotoxins}

Blood harbors several direct neurotoxins, all of which are present at levels above that which can kill neurons (Table 1).

Table 1. Blood components with direct neurotoxic effects, their concentration in whole blood, the concentration needed to achieve half-maximal neuronal death (LD50) in cultured neurons, and their blood concentration relative to their $\mathrm{LD}_{50}$.

\begin{tabular}{|c|c|c|c|}
\hline Blood Component & $\begin{array}{l}\text { Concentration in } \\
\text { Whole Blood }\end{array}$ & $\begin{array}{l}\text { LD }_{50} \text { in Neurons } \\
\text { at } 24 \mathrm{~h}\end{array}$ & $\begin{array}{l}\text { Blood Concentration } \\
\text { Relative to } \mathrm{LD}_{50}\end{array}$ \\
\hline Thrombin & $30 \mathrm{U} / \mathrm{mL}[26]$ & $\sim 4 \mathrm{U} / \mathrm{mL}[27]$ & $7.5 x$ \\
\hline Hemoglobin & $2.5 \mathrm{mM}[28]$ & $1-8 \mu \mathrm{M}[29,30]$ & $\sim 1000 \mathrm{x}$ \\
\hline Free Iron & $10-30 \mu \mathrm{M}$ & $\sim 10 \mu \mathrm{M}[31]$ & $1-3 x$ \\
\hline
\end{tabular}

Blood also contains numerous substances that exacerbate morbidity after CNS hemorrhage. In the following section, we discuss the various blood neurotoxins, including their mechanism of action and their maladaptive effects (Table 2). 
Table 2. Blood neurotoxins and their individual modes of toxicity.

\begin{tabular}{|c|c|c|}
\hline Component & Deleterious Effect & References \\
\hline \multirow{6}{*}{ Thrombin } & Neuron Death & {$[27,32-34]$} \\
\hline & Neuroinflammation & [35-41] \\
\hline & Cerebral Edema & [41-48] \\
\hline & Vasospasm & {$[48,49]$} \\
\hline & Hydrocephalus & {$[50,51]$} \\
\hline & Seizure & [52-54] \\
\hline Fibrinogen & Neuroinflammation & [55-59] \\
\hline \multirow{2}{*}{ Complement } & Neuroinflammation & [60-62] \\
\hline & Cerebral Edema & {$[61,63-67]$} \\
\hline Leukocytes & Neuroinflammation & [68-71] \\
\hline \multirow{2}{*}{ Platelets } & Neuroinflammation & [72] \\
\hline & Hydrocephalus & [73-75] \\
\hline \multirow{4}{*}{ Hemoglobin } & Neuron Death & {$[29,30,76-78]$} \\
\hline & Cerebral Edema & {$[63,79]$} \\
\hline & Seizure & [80] \\
\hline & Hydrocephalus & {$[81,82]$} \\
\hline \multirow{2}{*}{ Oxyhemoglobin } & Neuron Death & [83-86] \\
\hline & Vasospasm & {$[87,88]$} \\
\hline Methemoglobin & Neuroinflammation & [89] \\
\hline \multirow{3}{*}{ Hemin } & Neuron Death & {$[29,30]$} \\
\hline & Cerebral Edema & [79] \\
\hline & Neuroinflammation & [90] \\
\hline \multirow{4}{*}{ Iron } & Neuron Death & {$[31,91-94]$} \\
\hline & Cerebral Edema & {$[79,93]$} \\
\hline & Neuroinflammation & [93] \\
\hline & Hydrocephalus & [95] \\
\hline
\end{tabular}

\subsection{Thrombin}

Thrombin is a serine protease that is primarily generated by the liver as the prothrombin proenzyme and is best known as a key factor in the coagulation cascade via generation of fibrin [96,97]. Circulating prothrombin is matured to thrombin at the site of activation of the coagulation cascade [97]. While circulating thrombin is normally excluded by the blood-brain barrier (BBB), disruption of the BBB after acute CNS injury results in extravasation. In addition, thrombin is generated at low levels by most CNS cells in the normal healthy brain [98].

Independent from its role in coagulation, thrombin also serves as an important signaling molecule. Thrombin triggers cellular signal transduction through activation of a unique family of transmembrane receptors - the protease associated receptors (PARs) which are activated not by ligand binding, but by proteolytic cleavage of an exposed domain [99]. In the human CNS, PAR receptors are expressed by endothelium [100], neurons, microglia, and astrocytes [101]. PAR receptors are exquisitely sensitive to thrombin, with a half-maximal response achieved by only $\sim 50 \mathrm{pM}$ of thrombin [99].

After it crosses the BBB, thrombin triggers PAR-dependent neuroinflammation [35]. Thrombin mediates microglial activation and cytokine production [36,37], and astrocytic gliosis [38], cellular proliferation [102], and matrix metalloproteinase (MMP) production, which can mediate BBB breakdown [103]. In phagocytes, thrombin induces chemotaxis and secretion of proinflammatory cytokines [39].

Endothelial thrombin signaling is particularly pertinent to CNS hemorrhage. In brain endothelium, thrombin activates a transcriptional network that produces a proinflammatory and pro-angiogenic phenotype [40,41,44-46]. Endothelial cells that are exposed to thrombin respond with contraction and rounding [42] with downregulation 
and dysfunction of junctional proteins [43], and with increased angiogenesis and proliferation $[104,105]$. Together, these changes manifest as increased permeability to circulating plasma [41-43]

Thrombin has been associated with a variety of maladaptive secondary injury events after CNS hemorrhage. First, thrombin can directly mediate the death of CNS cells. After hemorrhage, thrombin triggers PAR-mediated apoptotic cell death of neurons [27,32-34], and contributes to perihematomal cell death and neuroparenchymal degeneration [106]. Second, thrombin induces contraction of vascular smooth muscle [107] and vasoconstriction of the cerebral vasculature [108], which may contribute to vasospasm following subarachnoid hemorrhage. In experimental subarachnoid hemorrhage, antagonism of thrombin reduces vasospasm and improves neurological outcome $[49,109]$. Third, thrombin is a major mediator of perihematomal vasogenic edema following ICH. Infusion of thrombin into brain tissue directly causes edema formation [110], whereas inhibition of thrombin with hirudin after experimental ICH decreases edema [111]. Fourth, thrombin has also been associated with hydrocephalus formation after IVH. Intraventricular thrombin injection results in PAR-1 dependent ventriculomegaly [50,51] and extravasation of plasma proteins, secondary to dysregulated cadherin expression [112]. Lastly, thrombin has pro-epileptogenic effects [52,53].

\subsection{Fibrinogen}

Fibrinogen is primarily produced by hepatocytes and is matured to fibrin at the site of coagulation by thrombin. Normally, fibrinogen is excluded by the BBB. Like thrombin, fibrinogen has a primary role as a pro-coagulant via its ability to cross-link platelets [58], and a secondary role as a modulator of neuroinflammation. Fibrinogen mediates microglial activation, ROS generation, and disease progression in the EAE model of multiple sclerosis [55]. Fibrinogen also triggers astrogliosis, astrocyte scar formation [56], and macrophage activation [57].

Fibrin contributes to neuroinflammation through two major mechanisms. Firstly, fibrin can directly interact with cell surface receptors. Upon conversion of fibrinogen to fibrin, an epitope is unmasked, which permits fibrin-mediated binding and activation of the microglial CD11b-CD18 integrin receptor, resulting in microglial activation $[58,59]$. Secondly, fibrin can serve as a carrier for cytokines, such as TGF- $\beta$ [56].

\subsection{Complement}

The complement cascade is a key mediator of innate cellular immunity and has important adaptive and maladaptive roles after CNS hemorrhage. Complement proteins are primarily synthesized by hepatocytes [113], although most components of the complement cascade can also be synthesized by CNS cells [114]. After CNS hemorrhage, complement activity is increased in the neuroparenchyma $[115,116]$. Evolutionarily, complement may serve to mediate clearance of apoptotic cellular debris, via opsonization of damaged and altered self-ligands [60,117].

Complement is a potent mediator of neuroinflammation. Complement activity generates two pro-inflammatory anaphylatoxins: $\mathrm{C} 3 \mathrm{a}$ and $\mathrm{C} 5 \mathrm{a}$. The anaphylatoxins, through their corresponding receptors (C3aR and C5aR) [118,119], stimulate phagocyte chemotaxis and transmigration, release of proinflammatory cytokines, and induction of oxidative burst [60]. C3 and C5 inhibition results in less microglial activation, neutrophil infiltration, and proinflammatory cytokine production after ICH [61,62].

Most importantly, complement is the primary mediator of a delayed form of vasogenic edema which occurs $\sim 3$ days after ICH. In delayed vasogenic edema, extravasated erythrocytes are lysed, spilling their edema-genic contents [63], as discussed in detail below. Complement mediates erythrocyte lysis at this time point [64] and is believed to initiate the formation of delayed vasogenic edema [61,65-67]. 


\subsection{Clot-Associated Cell Debris, Leukocytes, and Platelets}

The hematoma itself is comprised of millions of cells, including erythrocytes, white blood cells, and platelets, that are ultimately degraded and lysed, thereby spilling their contents and generating cellular debris. The immune system contains mechanisms to recognize damaged self-signals, so-called damage-associated molecular patterns (DAMPs), which are expressed by cellular debris. Notable DAMPs include the high mobility group box 1 (HMGB1) protein, S100 proteins, heat shock protein (HSP), and fibrinogen [120]. DAMPs are recognized and cleared by phagocytes via a family of Toll-like receptors (TLRs) [121]. After hemorrhage, TLR4 activity is upregulated, resulting in activation of phagocytes [122]. While controlled TLR activity is necessary for debris clearance, excessive activation has been associated with worsened neurological deficit and cerebral edema after brain hemorrhage [90].

Extravasated leukocytes worsen secondary injury following brain hemorrhage. In one interesting study, wild-type versus TLR4 knockout mice were submitted to experimental ICH with blood from either wild-type versus TLR4 knockout mice. Surprisingly, the wild-type mice injected with TLR4 knockout blood exhibited minimal deficits and fared better than the other groups [68], suggesting that immune signaling within the clot was a prime mediator of post-hemorrhage secondary injury. Indeed, circulating lymphocytes are critical mediators of neuroinflammation after ICH, with 30-day outcomes being linked to circulating lymphocyte counts [69]. Fingolimod, a sphingosine-1-phosphate modulator that depletes circulating lymphocytes, has been shown in animal and clinical studies to reduce circulating lymphocytes, reduce neuroinflammation and perihematomal edema, and improve neurological outcomes after ICH [70,71].

Extravasated platelets have also been shown to mediate secondary injury after $\mathrm{ICH}$. First, during coagulation and clotting, platelets release TGF- $\beta$, a 25-kD cytokine [75]. In animal experiments, ventricular TGF- $\beta$ can directly cause ventriculomegaly and communicating hydrocephalus $[73,74]$. After SAH in humans, TGF- $\beta$ is more abundant in the CSF of patients with hydrocephalus, and in patients that require CSF diversion [123]. Second, during coagulation, platelets generate and secrete HMGB1 [72]. HMGB1, which normally binds to nuclear DNA [124], also serves as a DAMP, thereby activating phagocytic cells through TLR2 and TLR4 ligation and NF-KB activation [125,126]. Activated immune cells subsequently can directly kill neurons through MMP and ROS production [127].

\subsection{Hemolysate}

CNS hemorrhage results in erythrocyte extravasation. During clearance of erythrocytes and hemoglobin, numerous toxic products are generated, which greatly contribute to morbidity after hemorrhage. Importantly, hemoglobin degradation is a normally beneficial and evolutionarily adaptive process and should not be viewed as a purely maladaptive phenomenon. Rather, it is only when the system becomes overwhelmed do toxic side-effects begin to accrue.

Intact erythrocytes are not inherently toxic. However, upon lysis, toxic intracellular components, collectively referred to as hemolysate, are released. Hemolysis is temporally delayed since MAC-mediated hemolysis occurs mostly at $\sim 3$ days after hemorrhage $[63,64]$. Hemolysate causes oxidative stress, neuroinflammation, and a variety of subsequent secondary injuries [63,78]. Hemolysate can also directly induce vasospasm of cerebral arteries $[128,129]$. Extravasated erythrocytes can be directly phagocytized. However, erythrocyte-laden macrophages often release their internalized heme or iron [130]. In addition, they may be killed by the ingested hemoglobin, resulting in spillage of their toxic contents [130].

After hemolysis, tetrameric hemoglobin is released from erythrocytes. Whole blood contains approximately $2.5 \mathrm{mM}$ of hemoglobin [28]. Released extracellular hemoglobin, which underlies the majority of hemolysate toxicity [131], then undergoes step-wise degradation, yielding toxic intermediates. Many of the hemoglobin breakdown products induce 
toxicity through generation of reactive oxygen species (ROS). ROS cause oxidation of cellular lipids, proteins, and DNA, resulting in programmed cell death [132].

Tetrameric hemoglobin either dissociates into dimers, which further decompose in the extracellular space, or is cleared by binding to haptoglobin, a circulating glycoprotein that is normally synthesized by the liver but can also be upregulated by glial cells after injury [133]. Hemoglobin binding results in a conformational change in haptoglobin, enabling its recognition and internalization via the CD163 receptor $[82,134]$. Interestingly, haptoglobin also slows auto-oxidation of hemoglobin and retards formation of toxic degradation products [135]. After hemorrhage, the binding capacity of haptoglobin is quickly overwhelmed [136].

Dimeric hemoglobin becomes oxidized to methemoglobin $\left(\mathrm{Fe}^{3+}\right)$, which upon exposure to reactive oxygen species can become further oxidized to ferryl hemoglobin $\left(\mathrm{Fe}^{4+}\right)$ [137]. Various modifications of the globin molecule can occur, including free radical formation and globin-globin crosslinks [137]. Hemoglobin derivatives spontaneously release their heme moiety, which becomes oxidized to hemin [28]. Extracellular hemin can be internalized by CNS cells either as a hemin-hemopexin complex via the low density lipoprotein receptor 1 (LRP1) [138,139], or as hemin alone through the heme carrier protein 1 (HCP1) [140]. Intracellular hemin is degraded by neuronal and glial heme oxygenase (HO)-1 or -2 in a NADPH-utilizing reaction to biliverdin, carbon monoxide, and free iron $[28,141]$. Biliverdin is processed to bilirubin, whereas the free iron is sequestered by ferritin [28,142], which is finally degraded to inert hemosiderin by lysosomes [28].

Nearly every stage of hemoglobin degradation is toxic. Hemoglobin causes apoptotic cell death of cultured CNS cells with an LD50 of $8 \mu \mathrm{M}$, which is substantially lower than the $2.5 \mathrm{mM}$ of hemoglobin found in blood $[29,30,76-78]$. When injected in vivo, hemoglobin causes neuronal death [143], edema formation [63,79], focal epileptiform activity [80], and ventriculomegaly [81,82]. Oxyhemoglobin, the auto-oxidized form of hemoglobin, is also toxic to cultured CNS cells [83-86] via generation of hydroxy radicals produced during its degradation to methemoglobin [86]. Importantly, through a combination of ROS generation and NO scavenging [144], oxyhemoglobin is a potent arterial spasmogen [87], and in primate models induces vasospasm with potency equal to whole blood [88]. Methemoglobin is a TLR4 agonist and can induce microglial activation and generation of pro-inflammatory cytokines [89]. Modified fragments of globin are similarly toxic, and can cause inflammation, inter-endothelial gap formation, and reduced junctional resistance [137].

Hemin, the oxidized form of heme, is strongly associated with neuronal death. Once completely released from hemoglobin, degraded blood contains approximately $10 \mathrm{mM}$ of hemin [28], which is approximately the LD50 for neurons [29,30]. Hemin is also associated with edema formation [79]. Hemin mediates toxicity through several mechanisms. Firstly, hemin can directly degrade hydrogen peroxide, thereby generating ROS and free radicals [28]. Secondly, hemin can intercalate into the plasmalemma and thereby sensitizes endothelial cells to ROS-mediated damage [145,146], resulting in lipid breakdown and impaired plasmalemmal function [147]. Thirdly, hemin can directly trigger TLR4 signaling and neuroinflammation [90]. Fourthly, heme induces endoplasmic reticulum and mitochondrial stress responses [148,149].

Hemin is degraded by HO into biliverdin, carbon monoxide (CO), and free iron, a reaction that constitutes the rate-limiting step of heme degradation. There exists conflicting data regarding the role of $\mathrm{HO}$ after CNS hemorrhage. In studies where $\mathrm{HO}$ is overexpressed after hemorrhage, investigators reported a protective role. This effect may be due to clearance of heme and generation of the antioxidants biliverdin and CO [150,151]. In other studies, $\mathrm{HO}$ activity was found to be maladaptive, with $\mathrm{HO}$ knockout resulting in reduced ROS generation and cell death $[152,153]$. These results may be due to an overload of ferritin binding capacity, and a depletion of intracellular NADPH, with subsequent depletion of glutathione [28]. The pleotropic roles of bilirubin and CO may also underlie the seemingly conflicting results. $\mathrm{CO}$ acts as a regulator of vascular tone, apoptosis 
and oxidative stress [154]. Bilirubin is a potent free radical scavenger that is also linked to encephalopathy.

Free iron itself is toxic. After ICH, free iron increases to a plateau at $\sim 2$ weeks and remains at elevated and toxic levels beyond 3 months after ictus $[155,156]$. Iron has been linked to dose-dependent CNS cell death [31,91-94], neuroinflammation [93], hydrocephalus [95], and edema formation [79,93]. Iron chelation is protective in many in vitro and in vivo models of CNS hemorrhage $[30,78,79,157]$. Iron mediates its toxic effects mostly through its ability to induce Fenton redox reactions with peroxides, resulting in production of ROS and free radicals [28]. In astrocytes, this process has been associated with loss of mitochondrial potential and ATP depletion [91].

\section{Clinical Evidence Supporting Early and Total Evacuation/Treatment of Intracranial Hemorrhage}

Having demonstrated the toxicity of blood, we now review the existing clinical literature on CNS hemorrhage with the hypothesis that interventions resulting in complete or near-complete evacuation and clearance of extravasated blood would be associated with improved outcomes following CNS hemorrhage. First, before examining the surgical literature, the medical management of $\mathrm{ICH}$ is reviewed and summarized in Table 3. Multiple RCTs for medical management, including varying levels of blood pressure control and multiple trials of pro-coagulant/pro-thrombotic agents, found no improvement in functional outcomes. The findings and analysis of medical managements of ICH trials have been summarized in a Cochrane Systematic Review last updated in 2018 [158]. Since no form of medical management addresses the complex neurotoxicity of CNS hemorrhage, the failure of these medical trials and future medical trials is not unexpected.

Table 3. Summary table of the major RCTs for medical management of intracerebral hemorrhage.

\begin{tabular}{|c|c|c|c|}
\hline Study & $\begin{array}{c}\text { Year } \\
\text { Published }\end{array}$ & Intervention & Outcome \\
\hline FAST [159] & 2008 & Factor VII vs. placebo & No difference in outcome \\
\hline INTERACT-2 [7] & 2013 & $\mathrm{BP}<140$ vs. $\mathrm{BP}<180 \mathrm{~mm} \mathrm{Hg}$ & No difference in outcome \\
\hline ATACH-2 [6] & 2016 & BP $110-139$ vs. $140-179 \mathrm{~mm} \mathrm{Hg}$ & No difference in outcome \\
\hline PATCH [8] & 2016 & $\begin{array}{l}\text { Platelet transfusion vs. } \\
\text { standard care }\end{array}$ & $\begin{array}{l}\text { Worse outcome in } \\
\text { transfusion group }\end{array}$ \\
\hline TICH-2 [10] & 2018 & Tranexamic Acid vs. placebo & No difference in outcome \\
\hline STOP-AUST [160] & 2020 & $\begin{array}{c}\text { Tranexamic Acid vs. placebo } \\
\text { for spot sign ICH }\end{array}$ & No difference in outcome \\
\hline I-DEF [161] & 2020 & $\begin{array}{l}\text { Deferoxamine Mesylate } \\
\text { vs. placebo }\end{array}$ & No difference in outcome \\
\hline
\end{tabular}

Next, a review of the surgical literature found many past trials of surgical evacuation of ICH as well as multiple systematic reviews and meta-analyses of those trials.

Critical to our analysis of the existing literature was to determine how effective these groups were in removing the blood clot, as our hypothesis is that those groups that removed the most blood would have better outcomes. However, a large majority of previous trials and retrospective studies did not include any determination or measurement of hematoma evacuation/clearance efficacy (Table 4). Likewise, the systematic reviews and meta-analyses that have been conducted on these trials suffer from the same issue of not having any measure or determination of hematoma evacuation efficacy within their analysis. Instead, they grossly compare the outcomes of surgical intervention versus non-intervention without first examining the efficacy of the intervention [162-164]. Not surprisingly, these systematic reviews have ambivalent conclusions about the efficacy of surgical intervention. 
Table 4. Summary of clinical literature evaluating the potential benefit of traditional open surgery and/or minimally invasive surgery for evacuation of intracerebral hemorrhage.

\begin{tabular}{|c|c|c|c|c|c|c|c|}
\hline Study & $\begin{array}{l}\text { Number of Study } \\
\text { Subjects (Surgery; } \\
\text { Control) }\end{array}$ & $\begin{array}{l}\text { Time from Onset to } \\
\text { Randomization * or } \\
\text { Treatment }\end{array}$ & $\begin{array}{l}\text { Hematoma Evacuation } \\
\text { Efficacy Measured? }\end{array}$ & $\begin{array}{c}\text { Average Rate of } \\
\text { Hematoma Evacuated } \\
\text { in Intervention Group }\end{array}$ & $\begin{array}{l}\text { Primary Surgical } \\
\text { Technique }\end{array}$ & Functional Benefit? & Mortality Benefit? \\
\hline $\begin{array}{l}\text { McKissock et al. (1961) } \\
\text { [165] }\end{array}$ & $\begin{array}{c}n=180 \\
\text { (89 surgery, } 91 \text { control) }\end{array}$ & $72 \mathrm{~h}$ & No & NA & $\begin{array}{l}\text { Open } \\
\text { Surgery }\end{array}$ & No & No \\
\hline Auer et al. (1989) [166] & $\begin{array}{c}n=100 \\
\text { (50 surgery; } 50 \text { control) }\end{array}$ & $48 \mathrm{~h}$ & Yes & $\begin{array}{c}\text { Est. Avg.: } 71 \% \\
50-70 \%: 56 \% \\
70-90 \%: 29 \% \\
90-100 \%: 15 \%\end{array}$ & Endoscopic Surgery & Yes & Yes \\
\hline Juvela et al. (1989) [167] & $\begin{array}{c}n=52 \\
\text { (56 surgery; } 56 \text { control) }\end{array}$ & $48 \mathrm{~h}$ & No & NA & Open Surgery & No & Yes \\
\hline Batjer et al. (1990) [168] & $\begin{array}{c}n=21 \\
\text { (8 surgerv; } 13 \text { control) }\end{array}$ & $24 h^{*}$ & No & NA & Open Surgery & No & No \\
\hline $\begin{array}{l}\text { Morgenstern et al. } \\
\text { (1998) [169] }\end{array}$ & $\begin{array}{c}n=34 \\
\text { (17 surgery; } 13 \text { control) }\end{array}$ & $\begin{array}{l}\text { Avg: } 1.2 \mathrm{~h} * \text { (surgery) } \\
\text { Avg: } 5.1 \mathrm{~h} * \text { (control) }\end{array}$ & No & NA & Open Surgery & No & No \\
\hline $\begin{array}{c}\text { Zuccarello et al. (1999) } \\
\text { [170] }\end{array}$ & $\begin{array}{c}n=20 \\
\text { (9 surgery; } 11 \text { control) }\end{array}$ & Avg: $8 \mathrm{~h}$ and $35 \mathrm{~min}$ & No & NA & $\begin{array}{c}\text { Open } \\
\text { Surgery/Stereotactic } \\
\text { aspiration (deep } \\
\text { hemorrhages) }\end{array}$ & $\begin{array}{l}\text { No (GOS or Rankin } \\
\text { Scale); lower follow-up } \\
\text { NIHSS in surgical } \\
\text { group }\end{array}$ & No \\
\hline $\begin{array}{c}\text { Teernstra et al. (2003) } \\
\text { [171] }\end{array}$ & $\begin{array}{c}n=70 \\
\text { (36 surgery; } 34 \text { control) }\end{array}$ & $72 \mathrm{~h}$ & Yes & $10-20 \%$ & Stereotactic thrombolysis & No & No \\
\hline $\begin{array}{l}\text { Hattori et al. (2004) } \\
\text { [172] }\end{array}$ & $\begin{array}{c}n=242 \\
(121 \text { surgery; } \\
121 \text { control) }\end{array}$ & $24 \mathrm{~h}$ & No & NA & Stereotactic & Yes & Yes \\
\hline $\begin{array}{l}\text { Mendelow et al. (2005) } \\
\text { [173] }\end{array}$ & $\begin{array}{c}n=964 \\
\text { (468 surgery; } \\
496 \text { control) }\end{array}$ & $\begin{array}{l}<72 \mathrm{~h} * \text { (Avg. time from } \\
\text { ictus to surgery: surgery } \\
30 \mathrm{~h} \text {; control } 60 \mathrm{~h} ¥)\end{array}$ & No & NA & Open Surgery & No & No \\
\hline $\begin{array}{c}\text { Pantazis et al. (2006) } \\
\text { [174] }\end{array}$ & $\begin{array}{c}n=108 \\
\text { (54 surgery; } 54 \text { control) }\end{array}$ & $8 \mathrm{~h}$ & No & NA & $\begin{array}{c}\text { Open Surgery (15-20 mm } \\
\text { dural incision) }\end{array}$ & Yes & No \\
\hline Wang et al. (2008) [175] & $\begin{array}{c}n=500 \\
\text { (266 surgery; } \\
234 \text { control) }\end{array}$ & $\begin{array}{c}\leq 7 \mathrm{~h} \\
7-24 \mathrm{~h} \\
\text { Or }>24 \mathrm{~h}\end{array}$ & No & NA & $\begin{array}{l}\text { MIS, endoscopic, } \\
\text { stereotactic, open surgery }\end{array}$ & Yes (those treated $<24 \mathrm{~h}$ ) & $\begin{array}{l}\text { Yes (those treated } \\
\quad<24 \mathrm{~h})\end{array}$ \\
\hline Miller et al. (2008) [176] & $\begin{array}{c}n=10 \\
\text { (6 surgery; } 4 \text { control) } \\
n=387\end{array}$ & $24 h$ * & Yes & Avg. $80 \%$ & Endoscopic & NA & NA \\
\hline Kim et al. (2009) [177] & $\begin{array}{l}\text { (284 surgery; } \\
183 \text { control) }\end{array}$ & 5 days & No & NA & Stereotactic & Yes & No \\
\hline
\end{tabular}


Table 4. Cont.

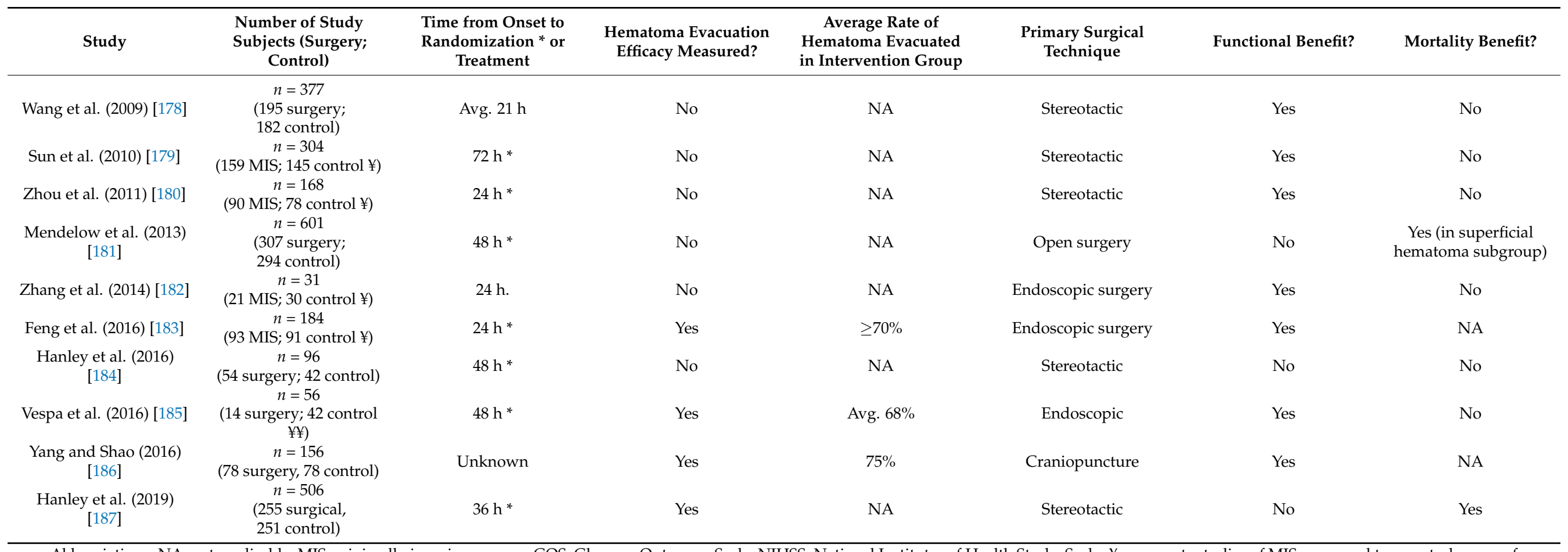

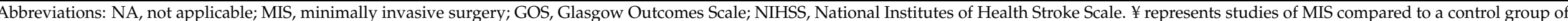
patients treated with open surgery. ¥¥ includes 36 patients comprising a contemporaneous medical control group from the MISTIE trial. 


\subsection{Intracerebral Hemorrhage: Evacuation Efficacy}

The existing literature on the surgical evacuation of ICH possesses several weaknesses in study design, including a lack of reporting of the extent of clot evacuation, inconsistency in the timing of the intervention, and the heterogeneity of surgical approaches of evacuation. Notably, few studies have reported on the extent of hematoma evacuation, which we posit to be a critical determinant of surgical intervention outcomes. Hematoma evacuation efficacy (HEE) is defined in Equation (1):

$$
\text { HEE }=((\text { Post-operative ICH volume/Pre-operative ICH volume }) \times 100 \%)
$$

Akin to the literature for thrombectomy for ischemic stroke, which found no benefit for thrombectomy with low recanalization rates, low HEE may suggest the need for better techniques rather than abandonment of surgical intervention altogether. Large randomized trials of ICH evacuation including STICH and STICH II found no improvement in outcome between surgical intervention and medical management [173,181]. However, neither study measured HEE. MISTIE III, a randomized trial of ICH evacuation via catheter-based thrombolysis, did measure hematoma evacuation rate and extent. While MISTIE III was not significant for its primary outcome, subsequent post hoc analyses found a significant increase in good functional outcome (mRS 0-3) in patients with final hematoma volume $<15$ cc compared to those with $\geq 15$ cc hemorrhage ( $53.1 \%$ vs. $32.7 \%$ ). Furthermore, patients with volume $<15 \mathrm{cc}$ also had outcomes significantly improved compared to the standard medical therapy group [188-190]. Another post hoc analysis of MISTIE III reported significant improvement in functional outcome in patients with end-of-treatment blood volume $<5$ cc compared to 5-10,10-20, and $>20$ cc [191]. In the last study, the 30 patients in the $<5 \mathrm{cc}$ group had a $73.3 \%$ rate of good functional outcome (mRS 0-3), while the $>20$ cc group had a $28.1 \%$ rate of good functional outcome. Evacuating another $15 \mathrm{cc}$ of blood (the difference between these two groups) resulted in $45.2 \%$ absolute change in rate of good functional outcome. Thus, while MISTIE III failed to show a benefit for surgical intervention, we posit that the subsequent post hoc analyses offer the strongest evidence to date that high HEE leads to dramatic improvement in functional outcomes.

In the smaller ICH evacuation studies that report HEE, there is a trend towards improved outcomes in the studies with the highest evacuation rates. Gross total hematoma removal has rarely been attempted in $\mathrm{ICH}$, with a single series of 176 patients showing faster improvement in functional status and decreased level of CSF neuroinflammatory markers compared to subtotal hematoma removal [192]. In contrast, a report on stereotactic thrombolysis of ICH, which recorded low (10-20\%) evacuation rates, failed to show any functional or mortality benefit with surgery [171]. Multiple reports of endoscopic ICH evacuation with recorded evacuation rates of $70-80 \%$ have shown improved functional outcomes and a mortality benefit in surgically treated patients $[166,176,183]$.

\subsection{Intracerebral Hemorrhage: Surgical Timing}

Many of the previously completed trials on surgical evacuation of ICH have primarily focused on non-emergent evacuation of the hemorrhage, with several patients being randomized to treatment or, less frequently undergoing treatment, within a range of $24-72 \mathrm{~h}$ following the ictus (Table 4). Based on current understanding of the pathophysiology of $\mathrm{ICH}$ and the ensuing secondary brain injury, these studies may have been set up for failure by nature of their design and the timing of surgical intervention.

Secondary injury refers to injury resulting from peri-hemorrhagic inflammation, toxic blood breakdown products, and perihematomal edema (PHE) that occurs following hemorrhage, which can contribute to neurologic deterioration several hours to days following the ictus [193]. PHE specifically increases most rapidly in the first two days following hemorrhage onset and can develop for up to two weeks [194]. PHE volume is directly related to the initial ICH volume at all times after the ictus and the rate of PHE expansion in the $72 \mathrm{~h}$ after the ictus is associated with poor functional outcomes in patients with deep $\mathrm{ICH}[193,195]$. 
Conceptually, it would seem most beneficial to evacuate ICH as early as possible to minimize the cascade of secondary injury and evolution of PHE. This concept is supported by animal models of ICH evacuation that have found that evacuation was most beneficial in terms of minimizing permanent neurologic deficit if performed within $6 \mathrm{~h}$ of onset. Evacuation was still beneficial, although to a lesser extent, if performed within $12 \mathrm{~h}$ of onset. Animals evacuated earlier had reduced brain edema formation, reduction in bloodbrain barrier disruption, and reduced perihematomal glutamate content, suggesting less secondary injury [196,197]. Analysis of MISTIE II evacuation showed surgical reduction in hematoma volume was associated with a parallel reduction in PHE volume [198].

The failure of large ICH evacuation trials including STICH I and STICH II may relate to the delay in surgical intervention. In these studies, the average times to surgery were 30 and $26.7 \mathrm{~h}$ for STICH I and STICH II, respectively $[173,181]$. Another comparison to the stroke thrombectomy literature may be appropriate, since in that literature, very few patients ultimately benefit from intervention after $6 \mathrm{~h}$. While the pathophysiology of ICH and ischemic stroke is quite different, the notion that "time is brain" may apply in both cases.

The study of timing of ICH evacuation in humans is extremely limited. Additionally, in studies that did report timing, very few also reported HEE. A randomized clinical trial by Wang et al. assessed the impact of surgical timing on 500 study subjects randomized to either surgical evacuation or medical therapy alone [178]. Perioperative and long-term functional outcomes, in addition to mortality, were improved in surgically treated patients relative to medically treated controls if surgery was performed in an ultra-early $(\leq 7 \mathrm{~h}$ from onset) or early (7-24 h) timeframe. Patients treated surgically beyond $24 \mathrm{~h}$ from onset did not experience any benefit in terms of functional outcome or mortality. Of note, the authors encourage exercising caution when operating in the ultra-early period due to an increased risk of re-hemorrhage [178].

In 1999, Zuccarello and colleagues called for the initiation of a randomized clinical trial of early or ultra-early ICH evacuation (within 3-6 h of onset) [170]. To date, no such study has been completed. However, the establishment of systems of care dedicated to rapid triage and management for acute thrombectomy for ischemic stroke over the past decade now make such a study feasible. Early surgical evacuation of $\mathrm{ICH}$, if performed in a minimally invasive fashion, may have the potential to minimize secondary injury, reduce edema and mass effect, and improve clinical outcomes. The future completion of such a study will be important for the advancement of ICH care and may offer the most promise in terms of improving patient outcomes.

\subsection{Intracerebral Hemorrhage: Method of Intervention}

Heterogeneity of surgical approaches to hematoma evacuation has plagued the ICH literature. Methods of surgical intervention for $\mathrm{ICH}$ previously reported include: decompressive craniectomy (DC) alone, DC + ICH evacuation, craniotomy (size not consistently reported) for evacuation, burr holes with stereotactic placement of drainage catheters, endoscopic-guided drainage of ICH, drainage using the Apollo suction system, and, most recently, image-guided minimally invasive hematoma evacuation using the BrainPath (NICO Corporation) system.

Consistent with the concept that blood is toxic to the brain and that it should be the primary target of any ICH intervention, DC alone has not been shown to improve functional outcomes. A systematic review and meta-analysis examining the efficacy of DC in ICH found no association with improved functional outcomes but did show a reduction in mortality rate, likely due to relief of mass effect [199]. The only RCT within the metaanalysis was a study of 40 patients comparing DC + ICH evacuation to ICH evacuation alone in patients with large $(>60 \mathrm{cc}$ ) ICH, which showed a significant increase in favorable outcome in the DC + ICH group compared to the ICH evacuation group [200]. This study reported many baseline and outcome data points but did not report HEE. In contrast, a small retrospective series comparing ICH evacuation with quantified HEE $(92 \%$ average 
evacuation) vs. ICH evacuation + DC found no benefit for the addition of DC in terms of functional outcome, suggesting near-complete hematoma evacuation alone is sufficient for treatment of ICH. Further, a multi-variate analysis showed post-operative hematoma volume $\leq 2 \mathrm{~mL}$ to be a significant predictor of good functional outcome, supporting the idea that gross total evacuation of ICH, rather than relief of mass effect, is the critical factor to improving outcomes [201].

Recent reports using the BrainPath system (NICO Corporation) have found encouraging results with high reported hematoma evacuation rates of $92 \%$ and $96 \%$ in two small series of 16 and 18 patients, respectively [202,203]. In a larger series of 39 patients treated with the BrainPath technique of hematoma evacuation, $>90 \%$ evacuation was achieved in $72 \%$ of patients [204]. The ongoing ENRICH (Early miNimally invasive Removal of IntraCerebral Hemorrhage) trial will offer further insight into the efficacy of this technique. An advantage of the BrainPath technique is not only its minimally invasive nature, but also its attention to avoidance of critical white matter tracts that may be overlying or adjacent to the ICH by use of reliable operative corridors to avoid these important regions.

\subsection{Intraventricular Hemorrhage}

ICH is often accompanied by bleeding into the cerebral ventricles, or intraventricular hemorrhage (IVH). IVH is associated with up to $50 \%$ mortality after $\mathrm{ICH}$, and can also occur with SAH, traumatic hemorrhage, or as an isolated hemorrhage [205]. In addition to predicting mortality, IVH is correlated with aseptic CSF inflammation [206].

Trials of IVH clearance support the notion that effective blood clearance improves outcomes, although they suffer from similar issues as the ICH trials including long periods from ictus to intervention and low clearance rates. The CLEAR trial examined the effect of IVH removal with intraventricular TPA (IVTPA) upon functional outcomes and mortality [207]. In this study, randomization occurred at $52 \mathrm{~h}$ with first IVTPA treatment given at $55 \mathrm{~h}$ on average. Thirty-three percent of patients in the IVTPA group achieved $80 \%$ clearance vs. $10 \%$ in the saline group. At 180 days, the IVTPA group had significantly lower mortality compared to control ( $18 \%$ vs. $29 \%)$, although this group did not demonstrate improved functional outcomes when compared to control. Higher absolute clearance rates are likely to be necessary to have a greater impact on outcomes. This is also suggested by a post hoc analysis of MISTIE III, which, while primarily focused on clearance of ICH, also showed that lower end-of-treatment IVH volumes are associated with significant improvements in good outcome [191]. Those patients with EOT IVH volumes of $>3 \mathrm{~mL}$ had $15 \%$ likelihood of achieving mRS 0-3 compared to $70 \%$ likelihood of achieving $\mathrm{mRS}$ 0-3 for those with EOT IVH volumes of $0 \mathrm{~mL}$.

The most direct, immediate method of IVH clearance that has been studied to date is endoscopically guided evacuation. Multiple small trials have shown favorable outcomes for endoscopic clearance of IVH when compared to EVD alone or EVD + tPA. In a 48-patient randomized trial comparing endoscopic IVH evacuation compared to EVD alone, the endoscopic evacuation group was found to have significantly lower shunt-dependent hydrocephalus with shorter ICU stays compared with EVD alone [208]. Another randomized trial of endoscopic IVH evacuation vs. EVD placement in the setting of thalamic ICH found endoscopic surgery to be associated with a lower GOS score and lower onset rates for shunt-dependent hydrocephalus and aspiration-related pneumonia in comparison to EVD [209]. High evacuation rate was associated with lower shunt-dependent rate and shorter hospitalization. A meta-analysis comparing endoscopic evacuation of IVH in the setting of ICH as compared to EVD + intraventricular fibrinolytics found an association of lower mortality (OR 0.31), higher effective hematoma evacuation rate (OR 25.50), higher likelihood of good functional outcome (OR 4.51), and lower rate of shunt dependence (OR 0.16) [210].

Lumbar drainage has also been examined as a mode of IVH clearance, either alone or as an adjunct to IVTPA. A prospective pilot trial in patients with IVH found that IVTPA + lumbar drain was associated with dramatically decreased shunt dependence [211]. A 
follow-up randomized trial by the same group examined use of IVTPA + lumbar drain compared to IVTPA alone for reducing the likelihood of shunt dependence [212]. The trial was stopped early due to the efficacy of the intervention. There were no patients $(0 / 14)$ in the IVTPA + lumbar drain group who ultimately required shunt placement compared to $43 \%$ of patients $(7 / 16)$ in the control group of IVTPA alone. Further, bleeding complications related to IVTPA administration were significantly less likely in the IVTPA + lumbar drain group (OR 0.401).

\subsection{Aneurysmal Subarachnoid Hemorrhage}

If the presumption that the toxicity of blood is the primary mediator of the deleterious effects of aSAH, then it should hold that the amount and quantity of aSAH blood should be predictive of DCI, vasospasm, and poor outcomes. Indeed, radiological scales of the quantity of subarachnoid blood, such as the Hijdra scale, are strongly predictive of DCI/vasospasm and functional outcome [213,214]. Volumetric quantification of subarachnoid blood also reliably predicts DCI (adjusted OR of 1.02 for every $1 \mathrm{~mL}$ of subarachnoid blood) [215]. A prospective, comparative study of volumetric quantification against traditional qualitative scales of SAH blood volumes showed higher AUC and discriminative ability to predict DCI and outcome [216]. The radiological density of subarachnoid blood, another proxy for blood burden, is also predictive of vasospasm [217]. In addition to being predictors of DCI, scales of blood burden, including mFS, independently predict outcome in poor-grade subarachnoid hemorrhage $[218,219]$. Highlighting a potential role for thrombin in vasospasm, aSAH patients with greater blood burden had higher CSF thrombin activity, slower clearance of blood, and increased vasospasm [220].

The above clinical data, in combination with the known toxicity of blood previously demonstrated, suggest that the rapid and complete clearance of toxic subarachnoid blood, through either direct clearance or indirect means, may reduce risk of DCI, vasospasm, and DIND and consequently improve outcome.

In aSAH patients with anterior communicating aneurysms requiring open aneurysmal clipping, cisternal clot evacuation along with fenestration of lamina terminalis was associated with decreased mortality from vasospasm and DIND [221]. Small trials of aSAH clearance via other direct clearance methods have shown decreased rates of DCI and improved outcomes. A small, matched cohort trial of direct cisternal lavage with urokinase with the objective of SAH clearance showed decreased rates of DCI and mortality with a trend towards decreased shunt dependence and improvement in functional outcomes at time of rehabilitation discharge [222]. The trial did not assess for efficacy of SAH clearance but mentioned that 9 of 20 patients with early CTs exhibited near complete resolution of $\mathrm{SAH}$. Increasing dosages of urokinase leading to increased clearance of drained blood were associated with less vasospasm in one study comparing differing dosages of urokinase [223]. Consecutive series of aSAH patients undergoing a similar cisternal irrigation method showed dramatically lower rate of vasospasm and DIND [224]. Intraoperative and post-operative cisternal irrigation with tPA has also been shown to be safe and effective for prevention of vasospasm [225]. One interesting study indicated that head shaking in conjunction to cisternal irrigation improved rates of vasospasm and DIND, presumably due to improved mobilization of clot [223]. Drainage of the cisterns does not seem to improve outcomes in patients with thin SAH, consistent with the theory that removing the toxic blood is the mechanism by which this intervention works [226].

Indirect clearance of aSAH via ventricular or lumbar drainage of CSF has also been shown to decrease rates of DCI/vasospasm and improve functional outcomes in multiple retrospective and prospective trials. A study that examined rates of symptomatic vasospasm in aSAH patients treated with external ventricular drain (EVD) compared to those who did not require EVD (NEVD) found significantly higher rates of vasospasm in the NEVD group despite the NEVD group having a much a higher population of low Hunt-Hess scale patients [227]. A small comparative study of ventricular drainage (EVD) vs. lumbar drainage patients showed that patients treated with lumbar drain had more 
rapid clearance of blood and significantly less new hypodense areas on $\mathrm{CT}$ compared to the EVD group, although both groups had similar rates of symptomatic vasospasm [228].

Multiple reports of lumbar drainage for aneurysmal subarachnoid hemorrhage have shown a decrease in DIND/vasospasm. Lumbar drainage has also been associated with shorter hospital stays and improved outcomes. The proposed mechanism involves increased clearance of cranial cisternal blood into the spinal subarachnoid space and lumbar cistern [229-231]. A retrospective study on 167 patients showed that lumbar drainage after SAH markedly reduces the risk of clinically evident vasospasm and its sequelae, shortens hospital stay, and improves outcome [229]. A prospective, randomized trial of $60 \mathrm{HH}$ II-IV SAH patients showed that lumbar CSF drainage reduced clinical and radiographic vasospasm and also showed improved outcomes and a trend toward a shorter hospital stay [230]. A systematic review of eight studies with 841 patients showed that lumbar drainage was associated with reduced rates of symptomatic vasospasm and improved clinical outcomes in patients with good clinical grade with thick clot burden [231]. The LUMAS trial of lumbar drainage examined 210 people of varying grades of aSAH and showed reduced rates of delayed ischemic neurological deficit and improved early outcomes with lumbar drainage [232]. A dual-lumen lumbar drainage system (Neurapheresis ${ }^{\mathrm{TM}}$ ) has been proposed as an alternative to simple lumbar drainage [233]. A recent clinical trial (PILLAR) has demonstrated safety and efficacy of this system, although further study is needed [234].

\section{Conclusions}

Intracranial blood, whether in the brain parenchyma, subarachnoid space, or ventricles, is toxic. The toxicity of blood in the CNS is related to its many components and breakdown products, which are harmful through a myriad of biological pathways. The past literature on medical management of intracranial hemorrhage is a history of failed trials, as no medical management conceived of thus far can adequately target all of the toxic pathways of blood and its breakdown products. The surgical literature of CNS hemorrhage evacuation and clearance, while also possessing a history of non-significant trials, has a uniting theme throughout: those trials that have tracked hematoma evacuation efficacy, whether in ICH, IVH, or aSAH, have found that high rates of HEE, or gross total evacuation, lead to improvements in functional outcomes. While surgical risk in clearing cerebral hemorrhage remains an important consideration, particularly in cases of deep hemorrhage, blood clearance via minimally invasive surgical evacuation, lumbar drainage, direct lavage and other modalities all hold promise for improving outcomes and decreasing the formidable morbidity of intracranial hemorrhages. The future of ICH, IVH, and aSAH research and management should be dedicated to the first principle that blood is toxic to the brain.

Author Contributions: Conceptualization, J.A.S. and G.J.C.; investigation, J.A.S., G.J.C., A.P.W., P.S., N.W.; data curation, J.A.S., G.J.C., A.P.W., P.S.; writing—original draft preparation J.A.S., G.J.C., A.P.W., P.S.; review and editing J.A.S., G.J.C., J.M.S.; supervision, J.M.S. All authors have read and agreed to the published version of the manuscript.

Funding: This research received no external funding.

Institutional Review Board Statement: Not applicable.

Informed Consent Statement: Not applicable.

Data Availability Statement: Not applicable.

Conflicts of Interest: The authors declare no conflict of interest. 


\section{References}

1. Hallevi, H.; Albright, K.C.; Aronowski, J.; Barreto, A.D.; Martin-Schild, S.; Khaja, A.M.; Gonzales, N.R.; Illoh, K.; Noser, E.A.; Grotta, J.C. Intraventricular hemorrhage: Anatomic relationships and clinical implications. Neurology 2008, 70, 848-852. [CrossRef] [PubMed]

2. An, S.J.; Kim, T.J.; Yoon, B.-W. Epidemiology, Risk Factors, and Clinical Features of Intracerebral Hemorrhage: An Update. J. Stroke 2017, 19, 3-10. [CrossRef] [PubMed]

3. Van Asch, C.J.; Luitse, M.J.; Rinkel, G.J.; van der Tweel, I.; Algra, A.; Klijn, C.J. Incidence, case fatality, and functional outcome of intracerebral haemorrhage over time, according to age, sex, and ethnic origin: A systematic review and meta-analysis. Lancet Neurol. 2010, 9, 167-176. [CrossRef]

4. Krishnamurthi, R.V.; Moran, A.E.; Forouzanfar, M.H.; Bennett, D.A.; Mensah, G.A.; Lawes, C.M.; Barker-Collo, S.; Connor, M.; Roth, G.A.; Sacco, R.; et al. The Global Burden of Hemorrhagic Stroke: A Summary of Findings from the GBD 2010 Study. Glob. Hear. 2014, 9, 101-106. [CrossRef] [PubMed]

5. Specogna, A.V.; Patten, S.B.; Turin, T.C.; Hill, M.D. Cost of Spontaneous Intracerebral Hemorrhage in Canada during 1 Decade. Stroke 2014, 45, 284-286. [CrossRef]

6. $\quad$ Qureshi, A.I.; Palesch, Y.Y.; Barsan, W.G.; Hanley, D.F.; Hsu, C.Y.; Martin, R.L.; Moy, C.S.; Silbergleit, R.; Steiner, T.; Suarez, J.I.; et al Intensive Blood-Pressure Lowering in Patients with Acute Cerebral Hemorrhage. N. Engl. J. Med. 2016, 375, 1033-1043. [CrossRef]

7. Anderson, C.S.; Heeley, E.; Huang, Y.; Wang, J.; Stapf, C.; Delcourt, C.; Lindley, R.; Robinson, T.; Lavados, P.; Neal, B.; et al. Rapid Blood-Pressure Lowering in Patients with Acute Intracerebral Hemorrhage. N. Engl. J. Med. 2013, 368, 2355-2365. [CrossRef]

8. Baharoglu, M.I.; Cordonnier, C.; Salman, R.A.-S.; de Gans, K.; Koopman, M.M.; Brand, A.; Majoie, C.B.; Beenen, L.F.A.; Marquering, H.; Vermeulen, M.; et al. Platelet transfusion versus standard care after acute stroke due to spontaneous cerebral haemorrhage associated with antiplatelet therapy (PATCH): A randomised, open-label, phase 3 trial. Lancet 2016, 387, 2605-2613. [CrossRef]

9. Mayer, S.A.; Brun, N.C.; Begtrup, K.; Broderick, J.; Davis, S.; Diringer, M.N.; Skolnick, B.E.; Steiner, T. Recombinant Activated Factor VII for Acute Intracerebral Hemorrhage. N. Engl. J. Med. 2005, 352, 777-785. [CrossRef]

10. Sprigg, N.; Flaherty, K.; Appleton, J.P.; Salman, R.A.-S.; Bereczki, D.; Beridze, M.; Christensen, H.; Ciccone, A.; Collins, R.; Czlonkowska, A.; et al. Tranexamic acid for hyperacute primary IntraCerebral Haemorrhage (TICH-2): An international randomised, placebo-controlled, phase 3 superiority trial. Lancet 2018, 391, 2107-2115. [CrossRef]

11. Chang, G.Y.; Davis, S.M.; Broderick, J.; Hennerici, M.; Brun, N.C.; Diringer, M.N.; Mayer, S.A.; Begtrup, K.; Steiner, T. Hematoma growth is a determinant of mortality and poor outcome after intracerebral hemorrhage. Neurology 2007, 68, 471-472. [CrossRef]

12. Safatli, D.A.; Günther, A.; Schlattmann, P.; Schwarz, F.; Kalff, R.; Ewald, C. Predictors of 30-day mortality in patients with spontaneous primary intracerebral hemorrhage. Surg. Neurol. Int. 2016, 7, S510-S517. [CrossRef]

13. Broderick, J.P.; Brott, T.G.E.; Duldner, J.; Tomsick, T.; Huster, G. Volume of intracerebral hemorrhage. A powerful and easy-to-use predictor of 30-day mortality. Stroke 1993, 24, 987-993. [CrossRef]

14. Tuhrim, S.; Horowitz, D.R.; Sacher, M.; Godbold, J.H. Volume of ventricular blood is an important determinant of outcome in supratentorial intracerebral hemorrhage. Crit. Care Med. 1999, 27, 617-621. [CrossRef] [PubMed]

15. Linn, F.H.; Rinkel, G.J.; Algra, A.; van Gijn, J. Incidence of subarachnoid hemorrhage: Role of region, year, and rate of computed tomography: A meta-analysis. Stroke 1996, 27, 625-629. [CrossRef] [PubMed]

16. Suarez, J.I.; Tarr, R.W.; Selman, W.R. Aneurysmal subarachnoid hemorrhage. N. Engl. J. Med. 2006, 354, 387-396. [CrossRef]

17. Van Gijn, J.; Rinkel, G.J. Subarachnoid haemorrhage: Diagnosis, causes and management. Brain 2001, 124, 249-278. [CrossRef] [PubMed]

18. Nieuwkamp, D.J.E.; Setz, L.; Algra, A.; Linn, F.H.; de Rooij, N.K.; Rinkel, G.J. Changes in case fatality of aneurysmal subarachnoid haemorrhage over time, according to age, sex, and region: A meta-analysis. Lancet Neurol. 2009, 8, 635-642. [CrossRef]

19. Hop, J.W.; Rinkel, G.J.; Algra, A.; van Gijn, J. Case-fatality rates and functional outcome after subarachnoid hemorrhage: A systematic review. Stroke 1997, 28, 660-664. [CrossRef] [PubMed]

20. English, S.W. Long-Term Outcome and Economic Burden of Aneurysmal Subarachnoid Hemorrhage: Are we Only Seeing the Tip of the Iceberg? Neurocrit Care 2020, 33, 37-38. [CrossRef] [PubMed]

21. Hoh, B.L.; Chi, Y.-Y.; Lawson, M.F.; Mocco, J.; Barker, I.F.G. Length of Stay and Total Hospital Charges of Clipping Versus Coiling for Ruptured and Unruptured Adult Cerebral Aneurysms in the Nationwide Inpatient Sample Database 2002 to. Stroke 2010, 41, 337-342. [CrossRef]

22. Ko, S.-B.; Choi, H.A.; Carpenter, A.M.; Helbok, R.; Schmidt, J.M.; Badjatia, N.; Claassen, J.; Connolly, E.S.; Mayer, S.A.; Lee, K. Quantitative Analysis of Hemorrhage Volume for Predicting Delayed Cerebral Ischemia After Subarachnoid Hemorrhage. Stroke 2011, 42, 669-674. [CrossRef]

23. Reilly, C.; Amidei, C.; Tolentino, J.; Jahromi, B.S.; Macdonald, R.L. Clot volume and clearance rate as independent predictors of vasospasm after aneurysmal subarachnoid hemorrhage. J. Neurosurg. 2004, 101, 255-261. [CrossRef] [PubMed]

24. Toyoda, T.; Yonekura, I.; Ijima, A.; Shinozaki, M.; Tanishima, T. Clot-Clearance Rate in the Sylvian Cistern Is Associated with the Severity of Cerebral Vasospasm After Subarachnoid Hemorrhage. Funct. Rehabil. Neurosurg. Neurotraumatol. 2014, 120, $275-277$. [CrossRef]

25. Adeoye, O.; Woo, D.; Haverbusch, M.; Sekar, P.; Moomaw, C.J.; Broderick, J.; Flaherty, M.L. Surgical Management and Case-Fatality Rates of Intracerebral Hemorrhage in 1988 and 2005. Neurosurgery 2008, 63, 1113-1118. [CrossRef] [PubMed] 
26. Mann, K.G.; Brummel, K.; Butenas, S. What is all that thrombin for? J. Thromb. Haemost. 2003, 1, 1504-1514. [CrossRef] [PubMed]

27. Xue, M.; Hollenberg, M.D.; Yong, V.W. Combination of Thrombin and Matrix Metalloproteinase-9 Exacerbates Neurotoxicity in Cell Culture and Intracerebral Hemorrhage in Mice. J. Neurosci. 2006, 26, 10281-10291. [CrossRef] [PubMed]

28. Robinson, S.R.; Dang, T.N.; Dringen, R.; Bishop, G.M. Hemin toxicity: A preventable source of brain damage following hemorrhagic stroke. Redox Rep. 2009, 14, 228-235. [CrossRef] [PubMed]

29. Regan, R.F.; Panter, S. Neurotoxicity of hemoglobin in cortical cell culture. Neurosci. Lett. 1993, 153, 219-222. [CrossRef]

30. Levy, Y.S.; Streifler, J.Y.; Panet, H.; Melamed, E.; Offen, D. Hemin-induced apoptosis in PC12 and neuroblastoma cells: Implications for local neuronal death associated with intracerebral hemorrhage. Neurotox. Res. 2002, 4, 609-616. [CrossRef]

31. Zhang, Y.; Tatsuno, T.; Carney, J.M.; Mattson, M.P. Basic FGF, NGF, and IGFs Protect Hippocampal and Cortical Neurons against Iron-Induced Degeneration. Br. J. Pharmacol. 1993, 13, 378-388. [CrossRef] [PubMed]

32. Smirnova, I.V.; Zhang, S.X.; Citron, B.A.; Arnold, P.M.; Festoff, B.W. Thrombin is an extracellular signal that activates intracellular death protease pathways inducing apoptosis in model motor neurons. J. Neurobiol. 1998, 36, 64-80. [CrossRef]

33. Jiang, Y.; Wu, J.; Hua, Y.; Keep, R.F.; Xiang, J.; Hoff, J.T.; Xi, G. Thrombin-Receptor Activation and Thrombin-Induced Brain Tolerance. Br. J. Pharmacol. 2002, 22, 404-410. [CrossRef]

34. Donovan, F.M.; Pike, C.J.; Cotman, C.W.; Cunningham, D.D. Thrombin Induces Apoptosis in Cultured Neurons and Astrocytes via a Pathway Requiring Tyrosine Kinase and RhoA Activities. J. Neurosci. 1997, 17, 5316-5326. [CrossRef] [PubMed]

35. Hua, Y.; Wu, J.; Keep, R.F.; Nakamura, T.; Hoff, J.T.; Xi, G. Tumor necrosis factor-alpha increases in the brain after intracerebral hemorrhage and thrombin stimulation. Neurosurgery 2006, 58, 542-550. [CrossRef]

36. Lan, X.; Han, X.; Li, Q.; Yang, Q.-W.; Wang, X.L.X.H.Q.L.J. Modulators of microglial activation and polarization after intracerebral haemorrhage. Nat. Rev. Neurol. 2017, 13, 420-433. [CrossRef] [PubMed]

37. Wan, S.; Cheng, Y.; Jin, H.; Guo, D.; Hua, Y.; Keep, R.F.; Xi, G. Microglia Activation and Polarization After Intracerebral Hemorrhage in Mice: The Role of Protease-Activated Receptor. Transl. Stroke Res. 2016, 7, 478-487. [CrossRef]

38. Nicole, O.; Goldshmidt, A.; Hamill, C.E.; Sorensen, S.D.; Sastre, A.; Lyuboslavsky, P.; Hepler, J.R.; McKeon, R.J.; Traynelis, S.F. Activation of Protease-Activated Receptor-1 Triggers Astrogliosis after Brain Injury. J. Neurosci. 2005, 25, 4319-4329. [CrossRef]

39. Bar-Shavit, R.; Kahn, A.; Fenton, J.W., 2nd; Wilner, G.D. Chemotactic response of monocytes to thrombin. J. Cell Biol. 1983, 96, 282-285. [CrossRef] [PubMed]

40. Minami, T.; Sugiyama, A.; Wu, S.-Q.; Abid, R.; Kodama, T.; Aird, W.C. Thrombin and Phenotypic Modulation of the Endothelium. Arter. Thromb. Vasc. Biol. 2004, 24, 41-53. [CrossRef]

41. Alabanza, L.M.; Bynoe, M.S. Thrombin induces an inflammatory phenotype in a human brain endothelial cell line. J. Neuroimmunol. 2012, 245, 48-55. [CrossRef] [PubMed]

42. Stasek, J.E.; Patterson, C.E.; Garcia, J.G.N. Protein kinase C phosphorylates caldesmon77 and vimentin and enhances albumin permeability across cultured bovine pulmonary artery endothelial cell monolayers. J. Cell. Physiol. 1992, 153, 62-75. [CrossRef] [PubMed]

43. Rabiet, M.-J.; Plantier, J.-L.; Rival, Y.; Genoux, Y.; Lampugnani, M.-G.; Dejana, E. Thrombin-Induced Increase in Endothelial Permeability Is Associated with Changes in Cell-to-Cell Junction Organization. Arter. Thromb. Vasc. Biol. 1996, 16, 488-496. [CrossRef]

44. Marin, V.; Farnarier, C.; Grès, S.; Kaplanski, S.; Su, M.S.-S.; Dinarello, C.A.; Kaplanski, G. The p38 mitogen-activated protein kinase pathway plays a critical role in thrombin-induced endothelial chemokine production and leukocyte recruitment. Blood 2001, 98, 667-673. [CrossRef]

45. Rahman, A.; Anwar, K.N.; True, A.L.; Malik, A.B. Thrombin-induced p65 homodimer binding to downstream NF-kappa B site of the promoter mediates endothelial ICAM-1 expression and neutrophil adhesion. J. Immunol. 1999, 162, 5466-5476.

46. Kaplanski, G.; Marin, V.; Fabrigoule, M.; Boulay, V.; Benoliel, A.M.; Bongrand, P.; Kaplanski, S.; Farnarier, C. Thrombin-activated human endothelial cells support monocyte adhesion in vitro following expression of intercellular adhesion molecule-1 (ICAM-1; CD54) and vascular cell adhesion molecule-1 (VCAM-1; CD106). Blood 1998, 92, 1259-1267. [CrossRef] [PubMed]

47. Pankonin, G.; Teuscher, E. Stimulation of endothelial cell migration by thrombin. Biomed. Biochim. Acta 1991, 50, $1073-1078$.

48. Duhamel-Clérin, E.; Orvain, C.; Lanza, F.; Cazenave, J.-P.; Klein-Soyer, C. Thrombin Receptor-Mediated Increase of Two Matrix Metalloproteinases, MMP-1 and MMP-3, in Human Endothelial Cells. Arter. Thromb. Vasc. Biol. 1997, 17, 1931-1938. [CrossRef]

49. Sugawara, T.; Jadhav, V.; Ayer, R.; Chen, W.; Suzuki, H.; Zhang, J.H. Thrombin Inhibition by Argatroban Ameliorates Early Brain Injury and Improves Neurological Outcomes After Experimental Subarachnoid Hemorrhage in Rats. Stroke 2009, 40, 1530-1532. [CrossRef]

50. Gao, F.; Liu, F.; Chen, Z.; Hua, Y.; Keep, R.F.; Xi, G. Hydrocephalus after Intraventricular Hemorrhage: The Role of Thrombin. Br. J. Pharmacol. 2013, 34, 489-494. [CrossRef]

51. Wan, Y.; Hua, Y.; Garton, H.J.L.; Novakovic, N.; Keep, R.F.; Xi, G. Activation of epiplexus macrophages in hydrocephalus caused by subarachnoid hemorrhage and thrombin. CNS Neurosci. Ther. 2019, 25, 1134-1141. [CrossRef]

52. Maggio, N.; Shavit, E.; Chapman, J.; Segal, M. Thrombin Induces Long-Term Potentiation of Reactivity to Afferent Stimulation and Facilitates Epileptic Seizures in Rat Hippocampal Slices: Toward Understanding the Functional Consequences of Cerebrovascular Insults. J. Neurosci. 2008, 28, 732-736. [CrossRef] [PubMed]

53. Lee, K.R.; Drury, I.; Vitarbo, E.; Hoff, J.T. Seizures induced by intracerebral injection of thrombin: A model of intracerebral hemorrhage. J. Neurosurg. 1997, 87, 73-78. [CrossRef] [PubMed] 
54. Isaeva, E.; Hernan, A.; Isaev, D.; Holmes, G.L. Thrombin facilitates seizures through activation of persistent sodium current. Ann. Neurol. 2012, 72, 192-198. [CrossRef] [PubMed]

55. Davalos, D.; Ryu, J.K.; Merlini, M.; Baeten, K.M.; Le Moan, N.; Petersen, M.A.; Deerinck, T.J.; Smirnoff, D.S.; Bedard, C.; Hakozaki, H.; et al. Fibrinogen-induced perivascular microglial clustering is required for the development of axonal damage in neuroinflammation. Nat. Commun. 2012, 3, 1227. [CrossRef] [PubMed]

56. Schachtrup, C.; Ryu, J.K.; Helmrick, M.J.; Vagena, E.; Galanakis, D.K.; Degen, J.L.; Margolis, R.U.; Akassoglou, K. Fibrinogen triggers astrocyte scar formation by promoting the availability of active TGF-beta after vascular damage. J. Neurosci. 2010, 30, 5843-5854. [CrossRef]

57. Smiley, S.T.; King, J.A.; Hancock, W.W. Fibrinogen Stimulates Macrophage Chemokine Secretion Through Toll-Like Receptor. J. Immunol. 2001, 167, 2887-2894. [CrossRef]

58. Petersen, M.A.; Ryu, J.K.; Akassoglou, K. Fibrinogen in neurological diseases: Mechanisms, imaging and therapeutics. Nat. Rev. Neurosci. 2018, 19, 283-301. [CrossRef]

59. Lishko, V.K.; Kudryk, B.; Yakubenko, V.P.; Yee, V.C.; Ugarova, T.P. Regulated unmasking of the cryptic binding site for integrin alpha M beta 2 in the gamma C-domain of fibrinogen. Biochemistry 2002, 41, 12942-12951. [CrossRef]

60. Brennan, F.H.; Anderson, A.J.; Taylor, S.M.; Woodruff, T.M.; Ruitenberg, M.J. Complement activation in the injured central nervous system: Another dual-edged sword? J. Neuroinflammation 2012, 9, 137. [CrossRef]

61. Yang, S.; Nakamura, T.; Hua, Y.; Keep, R.F.; Younger, J.G.; He, Y.; Hoff, J.T.; Xi, G. The Role of Complement C3 in Intracerebral Hemorrhage-Induced Brain Injury. Br. J. Pharmacol. 2006, 26, 1490-1495. [CrossRef]

62. Li, G.; Fan, R.-M.; Chen, J.-L.; Wang, C.-M.; Zeng, Y.-C.; Han, C.; Jiao, S.; Xia, X.-P.; Chen, W.; Yao, S.-T. Neuroprotective effects of argatroban and C5a receptor antagonist (PMX53) following intracerebral haemorrhage. Clin. Exp. Immunol. 2014, 175, 285-295. [CrossRef]

63. Xi, G.; Keep, R.F.; Hoff, J.T. Erythrocytes and delayed brain edema formation following intracerebral hemorrhage in rats. J. Neurosurg. 1998, 89, 991-996. [CrossRef] [PubMed]

64. Cao, S.; Zheng, M.; Guohua, X.; Chen, G.; Keep, R.F.; Xi, G. Hematoma Changes During Clot Resolution After Experimental Intracerebral Hemorrhage. Stroke 2016, 47, 1626-1631. [CrossRef]

65. Hua, Y.; Xi, G.; Keep, R.F.; Hoff, J.T. Complement activation in the brain after experimental intracerebral hemorrhage. J. Neurosurg. 2000, 92, 1016-1022. [CrossRef] [PubMed]

66. Xi, G.; Hua, Y.; Keep, R.F.; Younger, J.G.; Hoff, J.T. Systemic complement depletion diminishes perihematomal brain edema in rats. Stroke 2001, 32, 162-167. [CrossRef] [PubMed]

67. Rynkowski, A.M.; Kim, G.H.; Garrett, M.C.; Zacharia, E.B.; Otten, M.L.A.; Sosunov, S.; Komotar, R.J.; Hassid, B.G.; Ducruet, A.F.; Lambris, J.D.; et al. C3a Receptor Antagonist Attenuates Brain Injury after Intracerebral Hemorrhage. Br. J. Pharmacol. 2008, 29, 98-107. [CrossRef] [PubMed]

68. Sansing, L.H.; Harris, T.H.; Welsh, F.A.; Kasner, S.E.; Hunter, C.A.; Kariko, K. Toll-like receptor 4 contributes to poor outcome after intracerebral hemorrhage. Ann. Neurol. 2011, 70, 646-656. [CrossRef] [PubMed]

69. Su, W.; Gao, C.; Wang, P.; Huang, J.; Qian, Y.; Guo, L.; Zhang, J.; Jiang, R. Correlation of Circulating T Lymphocytes and Intracranial Hypertension in Intracerebral Hemorrhage. World Neurosurg. 2017, 107, 389-395. [CrossRef] [PubMed]

70. Rolland, W.B.; Lekic, T.; Krafft, P.R.; Hasegawa, Y.; Altay, O.; Hartman, R.; Ostrowski, R.; Manaenko, A.; Tang, J.; Zhang, J.H. Fingolimod reduces cerebral lymphocyte infiltration in experimental models of rodent intracerebral hemorrhage. Exp. Neurol. 2013, 241, 45-55. [CrossRef]

71. Fu, Y.; Hao, J.; Zhang, N.; Ren, L.; Sun, N.; Li, Y.J.; Yan, Y.; Huang, D.; Yu, C.; Shi, F.D. Fingolimod for the treatment of intracerebral hemorrhage: A 2-arm proof-of-concept study. JAMA Neurol. 2014, 71, 1092-1101. [CrossRef] [PubMed]

72. Imai, S.; Rauvala, H.; Parkkinen, J.; Rouhiainen, A. Occurrence of Amphoterin (HMG1) as an Endogenous Protein of Human Platelets that Is Exported to the Cell Surface upon Platelet Activation. Thromb. Haemost. 2000, 84, 1087-1094. [CrossRef]

73. Tada, T.; Kanaji, M.; Kobayashi, S. Induction of communicating hydrocephalus in mice by intrathecal injection of human recombinant transforming growth factor-beta. J. Neuroimmunol. 1994, 50, 153-158. [CrossRef]

74. Botfield, H.; Gonzalez, A.M.; Abdullah, O.; Skjolding, A.D.; Berry, M.; McAllister, J.P., 2nd; Logan, A. Decorin prevents the development of juvenile communicating hydrocephalus. Brain 2013, 136, 2842-2858. [CrossRef]

75. Grainger, D.J.; Wakefield, L.; Bethell, H.W.; Farndale, R.W.; Metcalfe, J.C. Release and activation of platelet latent TGF-beta in blood clots during dissolution with plasmin. Nat. Med. 1995, 1, 932-937. [CrossRef] [PubMed]

76. Wang, X.; Mori, T.; Sumii, T.; Lo, E.H. Hemoglobin-induced cytotoxicity in rat cerebral cortical neurons: Caspase activation and oxidative stress. Stroke 2002, 33, 1882-1888. [CrossRef]

77. Lara, F.A.; Kahn, S.; Da Fonseca, A.C.; Bahia, C.P.; Pinho, J.P.; Graca-Souza, A.V.; Houzel, J.C.; de Oliveira, P.L.; Moura-Neto, V.; Oliveira, M.F. On the Fate of Extracellular Hemoglobin and Heme in Brain. Br. J. Pharmacol. 2009, 29, 1109-1120. [CrossRef]

78. Jaremko, K.M.; Chen-Roetling, J.; Chen, L.; Regan, R.F. Accelerated hemolysis and neurotoxicity in neuron-glia-blood clot co-cultures. J. Neurochem. 2010, 114, 1063-1073. [CrossRef]

79. Huang, F.-P.; Xi, G.; Keep, R.F.; Hua, Y.; Nemoianu, A.; Hoff, J.T. Brain edema after experimental intracerebral hemorrhage: Role of hemoglobin degradation products. J. Neurosurg. 2002, 96, 287-293. [CrossRef]

80. Rosen, A.; Frumin, N. Focal epileptogenesis after intracortical hemoglobin injection. Exp. Neurol. 1979, 66, 277-284. [CrossRef] 
81. Strahle, J.M.; Garton, T.; Bazzi, A.A.; Kilaru, H.; Garton, H.J.; Maher, C.O.; Muraszko, K.M.; Keep, R.F.; Xi, G. Role of Hemoglobin and Iron in Hydrocephalus After Neonatal Intraventricular Hemorrhage. Neurosurgery 2014, 75, 696-706. [CrossRef] [PubMed]

82. Garton, T.P.; He, Y.; Garton, H.J.; Keep, R.F.; Xi, G.; Strahle, J.M. Hemoglobin-induced neuronal degeneration in the hippocampus after neonatal intraventricular hemorrhage. Brain Res. 2016, 1635, 86-94. [CrossRef] [PubMed]

83. Rollins, S.; Perkins, E.; Mandybur, G.; Zhang, J.H. Oxyhemoglobin produces necrosis, not apoptosis, in astrocytes. Brain Res. 2002, 945, 41-49. [CrossRef]

84. Ogihara, K.; Zubkov, A.Y.; Bernanke, D.H.; Lewis, A.I.; Parent, A.D.; Zhang, J.H. Oxyhemoglobin-induced apoptosis in cultured endothelial cells. J. Neurosurg. 1999, 91, 459-465. [CrossRef]

85. Meguro, T.; Chen, B.; Lancon, J.; Zhang, J.H. Oxyhemoglobin induces caspase-mediated cell death in cerebral endothelial cells. J. Neurochem. 2001, 77, 1128-1135. [CrossRef]

86. Steele, J.A.; Stockbridge, N.; Maljkovic, G.; Weir, B. Free radicals mediate actions of oxyhemoglobin on cerebrovascular smooth muscle cells. Circ. Res. 1991, 68, 416-423. [CrossRef]

87. Wellum, G.R.; Irvine, T.W.; Zervas, N.T. Dose responses of cerebral arteries of the dog, rabbit, and man to human hemoglobin in vitro. J. Neurosurg. 1980, 53, 486-490. [CrossRef]

88. Macdonald, R.L.; Weir, B.K.A.; Runzer, T.D.; Grace, M.G.A.; Findlay, J.M.; Saito, K.; Cook, D.A.; Mielke, B.W.; Kanamaru, K. Etiology of cerebral vasospasm in primates. J. Neurosurg. 1991, 75, 415-424. [CrossRef]

89. Kwon, M.S.; Woo, S.K.; Kurland, D.B.; Yoon, S.H.; Palmer, A.F.; Banerjee, U.; Iqbal, S.; Ivanova, S.; Gerzanich, V.; Simard, J.M. Methemoglobin Is an Endogenous Toll-Like Receptor 4 Ligand-Relevance to Subarachnoid Hemorrhage. Int. J. Mol. Sci. 2015, 16, 5028-5046. [CrossRef]

90. Lin, S.; Bing-Yin, S.; Zhong, Q.; Lv, F.-L.; Jing-Zhou, W.; Li, J.-Q.; Wang, J.-Z.; Su, B.-Y.; Yang, Q.-W. Heme activates TLR4-mediated inflammatory injury via MyD88/TRIF signaling pathway in intracerebral hemorrhage. J. Neuroinflamm. 2012, 9, 46. [CrossRef]

91. Robb, S.; Robb-Gaspers, L.; Scaduto, R.; Thomas, A.; Connor, J. Influence of calcium and iron on cell death and mitochondrial function in oxidatively stressed astrocytes. J. Neurosci. Res. 1999, 55, 674-686. [CrossRef]

92. Zhang, Z.; Wei, T.; Hou, J.; Li, G.; Yu, S.; Xin, W. Iron-induced oxidative damage and apoptosis in cerebellar granule cells: Attenuation by tetramethylpyrazine and ferulic acid. Eur. J. Pharmacol. 2003, 467, 41-47. [CrossRef]

93. Willmore, L.J.; Rubin, J.J. Formation of malonaldehyde and focal brain edema induced by subpial injection of $\mathrm{FeCl} 2$ into rat isocortex. Brain Res. 1982, 246, 113-119. [CrossRef]

94. Bishop, G.M.; Robinson, S.R. Quantitative analysis of cell death and ferritin expression in response to cortical iron: Implications for hypoxia-ischemia and stroke. Brain Res. 2001, 907, 175-187. [CrossRef]

95. Chen, Z.; Gao, C.; Hua, Y.; Keep, R.F.; Muraszko, K.; Xi, G. Role of Iron in Brain Injury After Intraventricular Hemorrhage. Stroke 2011, 42, 465-470. [CrossRef]

96. Strukova, S.M. Role of Platelets and Serine Proteinases in Coupling of Blood Coagulation and Inflammation. Biochemistry 2004, 69, 1067-1081. [CrossRef] [PubMed]

97. Davie, E.W.; Fujikawa, K.; Kisiel, W. The coagulation cascade: Initiation, maintenance, and regulation. Biochemistry 1991, 30, 10363-10370. [CrossRef] [PubMed]

98. Dihanich, M.; Kaser, M.; Reinhard, E.; Cunningham, D.; Monard, D. Prothrombin mRNA is expressed by cells of the nervous system. Neuron 1991, 6, 575-581. [CrossRef]

99. Vu, T.K.; Wheaton, V.I.; Hung, D.T.; Charo, I.; Coughlin, S.R. Domains specifying thrombin-receptor interaction. Nature 1991, 353, 674-677. [CrossRef]

100. Hirano, K. The Roles of Proteinase-Activated Receptors in the Vascular Physiology and Pathophysiology. Arter. Thromb. Vasc. Biol. 2007, 27, 27-36. [CrossRef] [PubMed]

101. Junge, C.E.; Lee, C.; Hubbard, K.B.; Zhang, Z.; Olson, J.J.; Hepler, J.R.; Brat, D.J.; Traynelis, S.F. Protease-activated receptor-1 in human brain: Localization and functional expression in astrocytes. Exp. Neurol. 2004, 188, 94-103. [CrossRef] [PubMed]

102. Wang, H.; Ubl, J.J.; Stricker, R.; Reiser, G. Thrombin (PAR-1)-induced proliferation in astrocytes via MAPK involves multiple signaling pathways. Am. J. Physiol. Physiol. 2002, 283, C1351-C1364. [CrossRef] [PubMed]

103. Choi, M.S.; Kim, Y.E.; Lee, W.J.; Choi, J.W.; Park, G.H.; Kim, S.D.; Jeon, S.J.; Go, H.S.; Shin, S.M.; Kim, W.-K.; et al. Activation of protease-activated receptor1 mediates induction of matrix metalloproteinase-9 by thrombin in rat primary astrocytes. Brain Res. Bull. 2008, 76, 368-375. [CrossRef] [PubMed]

104. Haralabopoulos, G.C.; Grant, D.S.; Kleinman, H.K.; Maragoudakis, M.E. Thrombin promotes endothelial cell alignment in Matrigel in vitro and angiogenesis in vivo. Am. J. Physiol. Physiol. 1997, 273, C239-C245. [CrossRef] [PubMed]

105. Tsopanoglou, N.E.; Maragoudakis, M.E. On the mechanism of thrombin-induced angiogenesis. Potentiation of vascular endothelial growth factor activity on endothelial cells by up-regulation of its receptors. J. Biol. Chem. 1999, 274, 23969-23976. [CrossRef] [PubMed]

106. Gong, Y.; Xi, G.; Hu, H.; Gu, Y.; Huang, F.; Keep, R.F.; Hua, Y. Increase in brain thrombin activity after experimental intracerebral hemorrhage. Neurosurg. Med. Ethics 2008, 105, 47-50. [CrossRef]

107. Ku, D.D.; Zaleski, J.K. Receptor Mechanism of Thrombin-Induced Endothelium-Dependent and Endothelium-Independent Coronary Vascular Effects in Dogs. J. Cardiovasc. Pharmacol. 1993, 22, 609-676. [CrossRef] [PubMed]

108. White, R.P.; Robertson, J.T. Role of plasmin, thrombin, and antithrombin III as etiological factors in delayed cerebral vasospasm. Neurosurgery 1985, 16, 27-35. [PubMed] 
109. Kai, Y.; Hirano, K.; Maeda, Y.; Nishimura, J.; Sasaki, T.; Kanaide, H. Prevention of the Hypercontractile Response to Thrombin by Proteinase-Activated Receptor-1 Antagonist in Subarachnoid Hemorrhage. Stroke 2007, 38, 3259-3265. [CrossRef]

110. Xi, G.; Wagner, K.R.; Keep, R.F.; Hua, Y.; De Courten-Myers, G.M.; Broderick, J.P.; Brott, T.G.; Hoff, J.T. Role of Blood Clot Formation on Early Edema Development After Experimental Intracerebral Hemorrhage. Stroke 1998, 29, 2580-2586. [CrossRef] [PubMed]

111. Lee, K.R.; Colon, G.P.; Betz, A.L.; Keep, R.F.; Kim, S.; Hoff, J.T. Edema from intracerebral hemorrhage: The role of thrombin. J. Neurosurg. 1996, 84, 91-96. [CrossRef] [PubMed]

112. Hao, X.; Le, C.; Zhang, H.; Shang, D.; Tong, L.; Gao, F. Thrombin disrupts vascular endothelial-cadherin and leads to hydrocephalus via protease-activated receptors-1 pathway. CNS Neurosci. Ther. 2019, 25, 1142-1150. [CrossRef]

113. Alper, C.A.; Johnson, A.M.; Birtch, A.G.; Moore, F.D. Human C'3: Evidence for the Liver as the Primary Site of Synthesis. Science 1969, 163, 286-288. [CrossRef] [PubMed]

114. Veerhuis, R.; Nielsen, H.M.; Tenner, A.J. Complement in the brain. Mol. Immunol. 2011, 48, 1592-1603. [CrossRef] [PubMed]

115. Lindsberg, P.J.; Öhman, J.; Lehto, T.; Wuorimaa, T.; Meri, S.; Karjalainen-Lindsberg, M.-L.; Paetau, A.; Carpén, O.; Kaste, M. Complement activation in the central nervous system following blood-brain barrier damage in man. Ann. Neurol. 1996, 40, 587-596. [CrossRef] [PubMed]

116. Van Dijk, B.J.; Meijers, J.C.M.; Kloek, A.T.; Knaup, V.L.; Rinkel, G.J.E.; Morgan, B.P.; van der Kamp, M.J.; Osuka, K.; Aronica, E.; Ruigrok, Y.M.; et al. Complement C5 Contributes to Brain Injury After Subarachnoid Hemorrhage. Transl Stroke Res 2019. [CrossRef]

117. Fishelson, Z.; Attali, G.; Mevorach, D. Complement and apoptosis. Mol. Immunol. 2001, 38, 207-219. [CrossRef]

118. Ames, R.S.; Li, Y.; Sarau, H.M.; Nuthulaganti, P.; Foley, J.J.; Ellis, C.; Zeng, Z.; Su, K.; Jurewicz, A.J.; Hertzberg, R.P.; et al. Molecular Cloning and Characterization of the Human Anaphylatoxin C3a Receptor. J. Biol. Chem. 1996, 271, 20231-20234. [CrossRef]

119. Gerard, N.P.; Gerard, C. The chemotactic receptor for human C5a anaphylatoxin. Nat. Cell Biol. 1991, 349, 614-617. [CrossRef]

120. Bianchi, M.E. DAMPs, PAMPs and alarmins: All we need to know about danger. J. Leukoc. Biol. 2007, 81, 1-5. [CrossRef]

121. Fang, H.; Wang, P.-F.; Zhou, Y.; Wang, Y.-C.; Yang, Q.-W. Toll-like receptor 4 signaling in intracerebral hemorrhage-induced inflammation and injury. J. Neuroinflammation 2013, 10, 27. [CrossRef] [PubMed]

122. Teng, W.; Wang, L.; Xue, W.; Guan, C. Activation of TLR4-mediated NFkappaB signaling in hemorrhagic brain in rats. Mediat. Inflamm 2009, 2009, 473276. [CrossRef]

123. Kitazawa, K.; Tada, T. Elevation of transforming growth factor-beta 1 level in cerebrospinal fluid of patients with communicating hydrocephalus after subarachnoid hemorrhage. Stroke 1994, 25, 1400-1404. [CrossRef] [PubMed]

124. Agresti, A.E.; Bianchi, M. HMGB proteins and gene expression. Curr. Opin. Genet. Dev. 2003, 13, 170-178. [CrossRef]

125. Park, J.S.; Svetkauskaite, D.; He, Q.; Kim, J.-Y.; Strassheim, D.; Ishizaka, A.; Abraham, E. Involvement of Toll-like Receptors 2 and 4 in Cellular Activation by High Mobility Group Box 1 Protein. J. Biol. Chem. 2004, 279, 7370-7377. [CrossRef]

126. Yang, D.; Chen, Q.; Yang, H.; Tracey, K.J.; Bustin, M.; Oppenheim, J.J. High mobility group box-1 protein induces the migration and activation of human dendritic cells and acts as an alarmin. J. Leukoc. Biol. 2006, 81, 59-66. [CrossRef]

127. Nguyen, H.X.; O’Barr, T.J.; Anderson, A.J. Polymorphonuclear leukocytes promote neurotoxicity through release of matrix metalloproteinases, reactive oxygen species, and TNF-alpha. J. Neurochem. 2007, 102, 900-912. [CrossRef]

128. Fujiwara, S.; Kuriyama, H. Hemolysate-induced contraction in smooth muscle cells of the guinea pig basilar artery. Stroke 1984, 15, 503-510. [CrossRef]

129. Toda, N. Hemolysate Inhibits Cerebral Artery Relaxation. Br. J. Pharmacol. 1988, 8, 46-53. [CrossRef]

130. Kondo, H.; Saito, K.; Grasso, J.P.; Aisen, P. Iron metabolism in the erythrophagocytosing Kupffer cell. Hepatology 1988, 8, 32-38. [CrossRef]

131. Mayberg, M.R.; Okada, T.; Bark, D.H. The role of hemoglobin in arterial narrowing after subarachnoid hemorrhage. J. Neurosurg. 1990, 72, 634-640. [CrossRef] [PubMed]

132. Sinha, K.; Das, J.; Pal, P.B.; Sil, P.C. Oxidative stress: The mitochondria-dependent and mitochondria-independent pathways of apoptosis. Arch. Toxicol. 2013, 87, 1157-1180. [CrossRef] [PubMed]

133. Lee, M.Y.; Kim, S.Y.; Choi, J.S.; Lee, I.H.; Choi, Y.S.; Jin, J.Y.; Park, S.J.; Sung, K.W.; Chun, M.H.; Kim, I.S. Upregulation of haptoglobin in reactive astrocytes after transient forebrain ischemia in rats. J. Cereb. Blood. Flow. Metab. 2002, 22, 1176-1180. [CrossRef]

134. Nielsen, M.J.; Petersen, S.V.; Jacobsen, C.; Thirup, S.; Enghild, J.J.; Graversen, J.H.; Moestrup, S.K. A Unique Loop Extension in the Serine Protease Domain of Haptoglobin Is Essential for CD163 Recognition of the Haptoglobin-Hemoglobin Complex. J. Biol. Chem. 2007, 282, 1072-1079. [CrossRef]

135. Cooper, C.E.; Schaer, D.J.; Buehler, P.W.; Wilson, M.T.; Reeder, B.J.; Silkstone, G.; Svistunenko, D.A.; Bulow, L.; Alayash, A.I. Haptoglobin binding stabilizes hemoglobin ferryl iron and the globin radical on tyrosine beta 145. Antioxid Redox Signal 2013, 18, 2264-2273. [CrossRef] [PubMed]

136. Bulters, D.; Gaastra, B.; Zolnourian, A.; Alexander, S.; Ren, D.; Blackburn, S.L.; Borsody, M.; Doré, S.; Galea, J.; Iihara, K.; et al. Haemoglobin scavenging in intracranial bleeding: Biology and clinical implications. Nat. Rev. Neurol. 2018, 14, 416-432. [CrossRef] 
137. Posta, N.; Csősz, É.; Oros, M.; Pethő, D.; Potor, L.; Kalló, G.; Hendrik, Z.; Sikura, K.É.; Méhes, G.; Tóth, C.; et al. Hemoglobin oxidation generates globin-derived peptides in atherosclerotic lesions and intraventricular hemorrhage of the brain, provoking endothelial dysfunction. Lab. Investig. 2020, 100, 986-1002. [CrossRef]

138. Smith, A.; Hunt, R.C. Hemopexin joins transferrin as representative members of a distinct class of receptor-mediated endocytic transport systems. Eur. J. Cell Biol. 1990, 53, 234-245. [PubMed]

139. Ishiguro, M.; Imai, Y.; Kohsaka, S. Expression and distribution of low density lipoprotein receptor-related protein mRNA in the rat central nervous system. Mol. Brain Res. 1995, 33, 37-46. [CrossRef]

140. Dang, T.N.; Bishop, G.M.; Dringen, R.; Robinson, S.R. The putative heme transporter HCP1 is expressed in cultured astrocytes and contributes to the uptake of hemin. Glia 2010, 58, 55-65. [CrossRef]

141. Scapagnini, G.; D'Agata, V.; Calabrese, V.; Pascale, A.; Colombrita, C.; Alkon, D.; Cavallaro, S. Gene expression profiles of heme oxygenase isoforms in the rat brain. Brain Res. 2002, 954, 51-59. [CrossRef]

142. Theil, E.C. Ferritin: Structure, gene regulation, and cellular function in animals, plants, and microorganisms. Annu. Rev. Biochem. 1987, 56, 289-315. [CrossRef]

143. Song, S.; Hua, Y.; Keep, R.F.; Hoff, J.T.; Xi, G. A new hippocampal model for examining intracerebral hemorrhage-related neuronal death: Effects of deferoxamine on hemoglobin-induced neuronal death. Stroke 2007, 38, 2861-2863. [CrossRef]

144. Hansen-Schwartz, J. Cerebral Vasospasm: A Consideration of the Various Cellular Mechanisms Involved in the Pathophysiology. Neurocritical Care 2004, 1, 235-246. [CrossRef]

145. Balla, J.; Jacob, H.S.; Balla, G.; Nath, K.; Eaton, J.W.; Vercellotti, G.M. Endothelial-cell heme uptake from heme proteins: Induction of sensitization and desensitization to oxidant damage. Proc. Natl. Acad. Sci. 1993, 90, 9285-9289. [CrossRef] [PubMed]

146. Balla, G.; Vercellotti, G.M.; Muller-Eberhard, U.; Eaton, J.; Jacob, H.S. Exposure of endothelial cells to free heme potentiates damage mediated by granulocytes and toxic oxygen species. Lab. Investig. 1991, 64, 648-655.

147. Balla, G.; Jacob, H.S.; Eaton, J.W.; Belcher, J.D.; Vercellotti, G.M. Hemin: A possible physiological mediator of low density lipoprotein oxidation and endothelial injury. Arter. Thromb. A J. Vasc. Biol. 1991, 11, 1700-1711. [CrossRef]

148. Gáll, T.; Pethő, D.; Nagy, A.; Hendrik, Z.; Méhes, G.; Potor, L.; Gram, M.; Åkerström, B.; Smith, A.; Nagy, P.; et al. Heme Induces Endoplasmic Reticulum Stress (HIER Stress) in Human Aortic Smooth Muscle Cells. Front. Physiol. 2018, 9. [CrossRef] [PubMed]

149. Higdon, A.N.; Benavides, G.A.; Chacko, B.K.; Ouyang, X.; Johnson, M.S.; Landar, A.; Zhang, J.; Darley-Usmar, V.M. Hemin causes mitochondrial dysfunction in endothelial cells through promoting lipid peroxidation: The protective role of autophagy. Am. J. Physiol. Heart Circ. Physiol. 2012, 302, H1394-H1409. [CrossRef]

150. Chen-Roetling, J.; Kamalapathy, P.; Cao, Y.; Song, W.; Schipper, H.M.; Regan, R.F. Astrocyte heme oxygenase-1 reduces mortality and improves outcome after collagenase-induced intracerebral hemorrhage. Neurobiol. Dis. 2017, 102, 140-146. [CrossRef]

151. Stocker, R.; Yamamoto, Y.; McDonagh, A.F.; Glazer, A.N.; Ames, B.N. Bilirubin is an antioxidant of possible physiological importance. Science 1987, 235, 1043-1046. [CrossRef] [PubMed]

152. Rogers, B.; Yakopson, V.; Teng, Z.-P.; Guo, Y.; Regan, R.F. Heme oxygenase-2 knockout neurons are less vulnerable to hemoglobin toxicity. Free. Radic. Biol. Med. 2003, 35, 872-881. [CrossRef]

153. Koeppen, A.H.; Dickson, A.C.; Smith, J. Heme Oxygenase in Experimental Intracerebral Hemorrhage: The Benefit of TinMesoporphyrin. J. Neuropathol. Exp. Neurol. 2004, 63, 587-597. [CrossRef] [PubMed]

154. Leffler, C.W.; Parfenova, H.; Jaggar, J.H. Carbon monoxide as an endogenous vascular modulator. Am. J. Physiol. Circ. Physiol. 2011, 301, H1-H11. [CrossRef] [PubMed]

155. Wu, J.; Hua, Y.; Keep, R.F.; Nakamura, T.; Hoff, J.T.; Xi, G. Iron and Iron-Handling Proteins in the Brain After Intracerebral Hemorrhage. Stroke 2003, 34, 2964-2969. [CrossRef] [PubMed]

156. Hua, Y.; Nakamura, T.; Keep, R.F.; Wu, J.; Schallert, T.; Hoff, J.T.; Xi, G. Long-term effects of experimental intracerebral hemorrhage: The role of iron. J. Neurosurg. 2006, 104, 305-312. [CrossRef] [PubMed]

157. Nakamura, T.; Keep, R.F.; Hua, Y.; Schallert, T.; Hoff, J.T.; Xi, G. Deferoxamine-induced attenuation of brain edema and neurological deficits in a rat model of intracerebral hemorrhage. J. Neurosurg. 2004, 100, 672-678. [CrossRef]

158. Al-Shahi Salman, R.; Law, Z.K.; Bath, P.M.; Steiner, T.; Sprigg, N. Haemostatic therapies for acute spontaneous intracerebral haemorrhage. Cochrane Database Syst. Rev. 2018, 4, CD005951. [CrossRef]

159. Mayer, S.A.; Brun, N.C.; Begtrup, K.; Broderick, J.; Davis, S.; Diringer, M.N.; Skolnick, B.E.; Steiner, T. Efficacy and Safety of Recombinant Activated Factor VII for Acute Intracerebral Hemorrhage. N. Engl. J. Med. 2008, 358, 2127-2137. [CrossRef] [PubMed]

160. Meretoja, A.; Yassi, N.; Wu, T.Y.; Churilov, L.; Sibolt, G.; Jeng, J.-S.; Kleinig, T.; Spratt, N.J.; Thijs, V.; Wijeratne, T.; et al. Tranexamic acid in patients with intracerebral haemorrhage (STOP-AUST): A multicentre, randomised, placebo-controlled, phase 2 trial. Lancet Neurol. 2020, 19, 980-987. [CrossRef]

161. Selim, M.; Foster, L.D.; Moy, C.S.; Xi, G.; Hill, M.D.; Morgenstern, L.B.; Greenberg, S.M.; James, M.L.; Singh, V.; Clark, W.M.; et al. Deferoxamine mesylate in patients with intracerebral haemorrhage (i-DEF): A multicentre, randomised, placebo-controlled, double-blind phase 2 trial. Lancet Neurol. 2019, 18, 428-438. [CrossRef]

162. Cavallo, C.; Zhao, X.; Abou-Al-Shaar, H.; Weiss, M.; Gandhi, S.; Belykh, E.; Tayebi-Meybodi, A.; Labib, M.A.; Preul, M.C.; Nakaji, P. Minimally invasive approaches for the evacuation of intracerebral hemorrhage: A systematic review. J. Neurosurg. Sci. 2018, 62, 718-733. [CrossRef] 
163. Rychen, J.; O’Neill, A.; Lai, L.T.; Bervini, D. Natural history and surgical management of spontaneous intracerebral hemorrhage: A systematic review. J. Neurosurg. Sci. 2021, 64, 558-570. [CrossRef]

164. Akhigbe, T.; Okafor, U.; Sattar, T.; Rawluk, D.; Fahey, T.; Ndoro, S.; Sattar, M. Stereotactic-Guided Evacuation of Spontaneous Supratentorial Intracerebral Hemorrhage: Systematic Review and Meta-Analysis. World Neurosurg. 2015, 84, 451-460. [CrossRef]

165. McKissock, W.R.A.; Taylor, J. Primary Intracerebral haematoma: A controlled trial of surgical and conservative treatment in 180 unselected cases. Lancet 1961, 278, 221-226. [CrossRef]

166. Auer, L.M.; Deinsberger, W.; Niederkorn, K.; Gell, G.; Kleinert, R.; Schneider, G.; Holzer, P.; Bone, G.; Mokry, M.; Körner, E.; et al. Endoscopic surgery versus medical treatment for spontaneous intracerebral hematoma: A randomized study. J. Neurosurg. 1989, 70, 530-535. [CrossRef]

167. Juvela, S.; Heiskanen, O.; Poranen, A.; Valtonen, S.; Kuurne, T.; Kaste, M.; Troupp, H. The treatment of spontaneous intracerebral hemorrhage. A prospective randomized trial of surgical and conservative treatment. J. Neurosurg. 1989, 70, 755-758. [CrossRef]

168. Batjer, H.H.; Reisch, J.S.; Allen, B.C.; Plaizier, L.J.; Su, C.J. Failure of Surgery to Improve Outcome in Hypertensive Putaminal Hemorrhage. Arch. Neurol. 1990, 47, 1103-1106. [CrossRef]

169. Morgenstern, L.B.; Frankowski, R.F.; Shedden, P.; Pasteur, W.; Grotta, J.C. Surgical treatment for intracerebral hemorrhage (STICH): A single-center, randomized clinical trial. Neurology 1998, 51, 1359-1363. [CrossRef]

170. Zuccarello, M.; Brott, T.; Derex, L.; Kothari, R.; Sauerbeck, L.; Tew, J.; Van Loveren, H.; Yeh, H.S.; Tomsick, T.; Pancioli, A.; et al. Early surgical treatment for supratentorial intracerebral hemorrhage: A randomized feasibility study. Stroke 1999, 30, 1833-1839. [CrossRef]

171. Teernstra, O.P.; Evers, S.M.; Lodder, J.; Leffers, P.; Franke, C.L.; Blaauw, G. Multicenter randomized controlled t. Stereotactic treatment of intracerebral hematoma by means of a plasminogen activator: A multicenter randomized controlled trial (SICHPA). Stroke 2003, 34, 968-974. [CrossRef] [PubMed]

172. Hattori, N.; Katayama, Y.; Maya, Y.; Gatherer, A. Impact of stereotactic hematoma evacuation on activities of daily living during the chronic period following spontaneous putaminal hemorrhage: A randomized study. J. Neurosurg. 2004, 101, 417-420. [CrossRef] [PubMed]

173. Mendelow, A.D.; Gregson, B.A.; Fernandes, H.M.; Murray, G.D.; Teasdale, G.M.; Hope, D.T.; Karimi., A.; Shaw, M.D.; Barer, D.H.; STITCH Investigators. Early surgery versus initial conservative treatment in patients with spontaneous supratentorial intracerebral haematomas in the International Surgical Trial in Intracerebral Haemorrhage (STICH): A randomised trial. Lancet 2005, 365, 387-397. [CrossRef]

174. Pantazis, G.; Tsitsopoulos, P.; Mihas, C.; Katsiva, V.; Stavrianos, V.; Zymaris, S. Early surgical treatment vs conservative management for spontaneous supratentorial intracerebral hematomas: A prospective randomized study. Surg. Neurol. 2006, 66, 492-501. [CrossRef]

175. Wang, Y.F.; Wu, J.S.; Mao, Y.; Chen, X.C.; Zhou, L.F.; Zhang, Y. The optimal time-window for surgical treatment of spontaneous intracerebral hemorrhage: Result of prospective randomized controlled trial of 500 cases. Neurosurg. Med Ethics 2008, 105, 141-145. [CrossRef]

176. Miller, C.M.; Vespa, P.; Saver, J.L.; Kidwell, C.S.; Carmichael, S.T.; Alger, J.; Frazee, J.; Starkman, S.; Liebeskind, D.; Nenov, V.; et al. Image-guided endoscopic evacuation of spontaneous intracerebral hemorrhage. Surg. Neurol. 2008, 69, 441-446. [CrossRef]

177. Kim, Y.Z.; Kim, K.H. Even in Patients with a Small Hemorrhagic Volume, Stereotactic-Guided Evacuation of Spontaneous Intracerebral Hemorrhage Improves Functional Outcome. J. Korean Neurosurg. Soc. 2009, 46, 109-115. [CrossRef]

178. Wang, W.-Z.; Jiang, B.; Liu, G.-M.; Li, D.; Lu, C.-Z.; Zhao, Y.-D.; Sander, J.W.; Liu, H.G.-M. Minimally Invasive Craniopuncture Therapy vs. Conservative Treatment for Spontaneous Intracerebral Hemorrhage: Results from a Randomized Clinical Trial in China. Int. J. Stroke 2009, 4, 11-16. [CrossRef]

179. Sun, H.; Liu, H.; Li, D.; Liu, L.; Yang, J.; Wang, W. An effective treatment for cerebral hemorrhage: Minimally invasive craniopuncture combined with urokinase infusion therapy. Neurol. Res. 2010, 32, 371-377. [CrossRef]

180. Zhou, H.; Zhang, Y.; Liu, L.; Han, X.; Tao, Y.; Tang, Y.; Hua, W.; Xue, J.; Dong, Q. A prospective controlled study: Minimally invasive stereotactic puncture therapy versus conventional craniotomy in the treatment of acute intracerebral hemorrhage. $B M C$ Neurol. 2011, 11, 76. [CrossRef]

181. Mendelow, A.D.A.; Gregson, B.; Rowan, E.N.; Murray, G.D.; Gholkar, A.; Mitchell, P.M. Early surgery versus initial conservative treatment in patients with spontaneous supratentorial lobar intracerebral haematomas (STICH II): A randomised trial. Lancet 2013, 382, 397-408. [CrossRef]

182. Zhang, H.-Z.; Li, Y.-P.; Yan, Z.-C.; Wang, X.-D.; She, L.; Wang, X.-D.; Dong, L. Endoscopic Evacuation of Basal Ganglia Hemorrhage via Keyhole Approach Using an Adjustable Cannula in Comparison with Craniotomy. BioMed Res. Int. 2014, 2014, 1-6. [CrossRef] [PubMed]

183. Feng, Y.; He, J.; Liu, B.; Yang, L.; Wang, Y. Endoscopic-assisted keyhole technique for hypertensive cerebral hemorrhage in elderly patients: A randomized controlled study in 184 patients. Turk. Neurosurg. 2015, 26, 84-89. [CrossRef] [PubMed]

184. Hanley, D.F.E.; Thompson, R.; Muschelli, J.; Rosenblum, M.; McBee, N.; Lane, K.; Bistran-Hall, A.J.; Mayo, S.W.; Keyl, P.; Gandhi, D.; et al. Safety and efficacy of minimally invasive surgery plus alteplase in intracerebral haemorrhage evacuation (MISTIE): A randomised, controlled, open-label, phase 2 trial. Lancet Neurol. 2016, 15, 1228-1237. [CrossRef] 
185. Vespa, P.; Hanley, D.; Betz, J.; Hoffer, A.; Engh, J.; Carter, R.; Nakaji, P.; Ogilvy, C.; Jallo, J.; Selman, W.; et al. ICES (Intraoperative Stereotactic Computed Tomography-Guided Endoscopic Surgery) for Brain Hemorrhage: A Multicenter Randomized Controlled Trial. Stroke 2016, 47, 2749-2755. [CrossRef]

186. Yang, G.; Shao, G. Clinical effect of minimally invasive intracranial hematoma in treating hypertensive cerebral hemorrhage. Pak J. Med Sci. 2016, 32, 677-681. [CrossRef]

187. Hanley, D.F.E.; Thompson, R.; Rosenblum, M.; Yenokyan, G.; Lane, K.; McBee, N.; Mayo, S.W.; Bistran-Hall, A.J.; Gandhi, D.; Mould, W.A.; et al. Efficacy and safety of minimally invasive surgery with thrombolysis in intracerebral haemorrhage evacuation (MISTIE III): A randomised, controlled, open-label, blinded endpoint phase 3 trial. Lancet 2019, 393, 1021-1032. [CrossRef]

188. Ziai, W.C.; McBee, N.; Lane, K.; Lees, K.R.; Dawson, J.; Vespa, P.; Thompson, R.E.; Mendelow, A.D.; Kase, C.S.; Carhuapoma, J.R.; et al. A randomized 500-subject open-label phase 3 clinical trial of minimally invasive surgery plus alteplase in intracerebral hemorrhage evacuation (MISTIE III). Int. J. Stroke 2019, 14, 548-554. [CrossRef]

189. Sattur, M.G.; Spiotta, A.M. Commentary: Efficacy and Safety of Minimally Invasive Surgery With Thrombolysis in Intracerebral Haemorrhage Evacuation (MISTIE III): A Randomized, Controlled, Open-Label, Blinded Endpoint Phase 3 Trial. Neurosurgery 2020, 86, E444-E446. [CrossRef]

190. Awad, A.I.; Polster, S.P.; Carrión-Penagos, J.E.; Thompson, R.; Cao, Y.; Stadnik, A.; Money, P.L.; Fam, M.D.; Koskimäki, J.; Girard, R.; et al. Surgical Performance Determines Functional Outcome Benefit in the Minimally Invasive Surgery Plus Recombinant Tissue Plasminogen Activator for Intracerebral Hemorrhage Evacuation (MISTIE) Procedure. Neurosurgery 2019, 84, 1157-1168. [CrossRef]

191. De Havenon, A.; Joyce, E.; Yaghi, S.; Ansari, S.; Delic, A.; Taussky, P.; Alexander, M.; Tirschwell, D.; Grandhi, R. End-of-Treatment Intracerebral and Ventricular Hemorrhage Volume Predicts Outcome: A Secondary Analysis of MISTIE III. Stroke 2020, 51, 652-654. [CrossRef] [PubMed]

192. Zuo, Y.; Cheng, G.; Gao, D.-K.; Zhang, X.; Zhen, H.-N.; Zhang, W.; Xiao, S.-C. Gross-total hematoma removal of hypertensive basal ganglia hemorrhages: A long-term follow-up. J. Neurol. Sci. 2009, 287, 100-104. [CrossRef]

193. Urday, S.; Kimberly, W.T.; Beslow, L.A.; Vortmeyer, A.O.; Selim, M.H.; Rosand, J.; Simard, J.M.; Sheth, K.N. Targeting secondary injury in intracerebral haemorrhage-perihaematomal oedema. Nat. Rev. Neurol. 2015, 11, 111-122. [CrossRef]

194. Venkatasubramanian, C.; Mlynash, M.; Finley-Caulfield, A.; Eyngorn, I.; Kalimuthu, R.; Snider, R.W.; Wijman, C.A. Natural History of Perihematomal Edema After Intracerebral Hemorrhage Measured by Serial Magnetic Resonance Imaging. Stroke 2011, 42, 73-80. [CrossRef]

195. Grunwald, Z.; Beslow, L.A.; Urday, S.; Vashkevich, A.; Ayres, A.; Greenberg, S.M.; Goldstein, J.N.; Leasure, A.; Shi, F.-D.; Kahle, K.T.; et al. Perihematomal Edema Expansion Rates and Patient Outcomes in Deep and Lobar Intracerebral Hemorrhage. Neurocritical Care 2016, 26, 205-212. [CrossRef]

196. Wang, L.; Wang, F.; Wu, G.; Shi, J. Early-stage minimally invasive procedures decrease perihematomal endothelin-1 levels and improve neurological functioning in a rabbit model of intracerebral hemorrhage. Neurol. Res. 2014, 37, 320-327. [CrossRef]

197. Wu, G.; Sheng, F.; Wang, L.; Wang, F. The pathophysiological time window study of performing minimally invasive procedures for the intracerebral hematoma evacuation in rabbit. Brain Res. 2012, 1465, 57-65. [CrossRef]

198. Mould, W.A.; Carhuapoma, J.R.; Muschelli, J.; Lane, K.; Morgan, T.C.; McBee, N.A.; Bistran-Hall, A.J.; Ullman, N.L.; Vespa, P.; Martin, N.A.; et al. Minimally invasive surgery plus recombinant tissue-type plasminogen activator for intracerebral hemorrhage evacuation decreases perihematomal edema. Stroke 2013, 44, 627-634. [CrossRef]

199. Yao, Z.; Ma, L.; You, C.; He, M. Decompressive Craniectomy for Spontaneous Intracerebral Hemorrhage: A Systematic Review and Meta-analysis. World Neurosurg. 2018, 110, 121-128. [CrossRef]

200. Moussa, W.M.M.; Khedr, W. Decompressive craniectomy and expansive duraplasty with evacuation of hypertensive intracerebral hematoma, a randomized controlled trial. Neurosurg. Rev. 2016, 40, 115-127. [CrossRef]

201. Shimamura, N.; Munakata, A.; Naraoka, M.; Nakano, T.; Ohkuma, H. Decompressive Hemi-craniectomy Is Not Necessary to Rescue Supratentorial Hypertensive Intracerebral Hemorrhage Patients: Consecutive Single-Center Experience. Neurosurg. Med. Ethics 2011, 111, 415-419. [CrossRef]

202. Rutkowski, M.; Song, I.; Mack, W.; Zada, G. Outcomes After Minimally Invasive Parafascicular Surgery for Intracerebral Hemorrhage: A Single-Center Experience. World Neurosurg. 2019, 132, e520-e528. [CrossRef]

203. Bauer, A.M.; Rasmussen, P.A.; Bain, M.D. Initial Single-Center Technical Experience With the BrainPath System for Acute Intracerebral Hemorrhage Evacuation. Oper. Neurosurg. 2017, 13, 69-76. [CrossRef]

204. Labib, M.A.; Shah, M.; Kassam, A.B.; Young, R.; Zucker, L.; Maioriello, A.; Britz, G.; Agbi, C.; Day, J.D.; Gallia, G.; et al. The Safety and Feasibility of Image-Guided BrainPath-Mediated Transsulcul Hematoma Evacuation: A Multicenter Study. Neurosurgery 2017, 80, 515-524. [CrossRef]

205. Steiner, T.; Diringer, M.N.; Schneider, D.; Mayer, S.A.; Begtrup, K.; Broderick, J.; Skolnick, B.E.; Davis, S.M. Dynamics of Intraventricular Hemorrhage in Patients with Spontaneous Intracerebral Hemorrhage: Risk Factors, Clinical Impact, and Effect of Hemostatic Therapy with Recombinant Activated Factor VII. Neurosurgery 2006, 59, 767-774. [CrossRef]

206. Fam, M.D.; Zeineddine, H.A.; Eliyas, J.K.; Stadnik, A.; Jesselson, M.; McBee, N.; Lane, K.; Cao, Y.; Wu, M.; Zhang, L.; et al. CSF inflammatory response after intraventricular hemorrhage. Neurology 2017, 89, 1553-1560. [CrossRef] 
207. Ziai, W.C.; Tuhrim, S.; Lane, K.; McBee, N.; Lees, K.; Dawson, J.; Butcher, K.; Vespa, P.; Wright, D.W.; Keyl, P.M.; et al. A Multicenter, Randomized, Double-Blinded, Placebo-Controlled Phase III Study of Clot Lysis Evaluation of Accelerated Resolution of Intraventricular Hemorrhage (CLEAR III). Int. J. Stroke 2013, 9, 536-542. [CrossRef]

208. Chen, C.-C.; Liu, C.-L.; Tung, Y.-N.; Lee, H.-C.; Chuang, H.-C.; Lin, S.-Z.; Cho, D.-Y. Endoscopic Surgery for Intraventricular Hemorrhage (IVH) Caused by Thalamic Hemorrhage: Comparisons of Endoscopic Surgery and External Ventricular Drainage (EVD) Surgery. World Neurosurg. 2011, 75, 264-268. [CrossRef] [PubMed]

209. Shimizu, Y.; Tsuchiya, K.; Fujisawa, H. Endoscopic surgery for thalamic hemorrhage with intraventricular hemorrhage: Effects of combining evacuation of a thalamic hematoma to external ventricular drainage. Asian, J. Neurosurg. 2019, 14, 1112-1115. [CrossRef] [PubMed]

210. Li, Y.; Zhang, H.; Wang, X.; She, L.; Yan, Z.; Zhang, N.; Du, R.; Yan, K.; Xu, E.; Pang, L. Neuroendoscopic Surgery versus External Ventricular Drainage Alone or with Intraventricular Fibrinolysis for Intraventricular Hemorrhage Secondary to Spontaneous Supratentorial Hemorrhage: A Systematic Review and Meta-Analysis. PLoS ONE 2013, 8, e80599. [CrossRef]

211. Staykov, D.; Huttner, H.B.; Struffert, T.; Ganslandt, O.; Doerfler, A.; Schwab, S.; Bardutzky, J. Intraventricular Fibrinolysis and Lumbar Drainage for Ventricular Hemorrhage. Stroke 2009, 40, 3275-3280. [CrossRef]

212. Staykov, D.; Kuramatsu, J.B.; Bardutzky, J.; Volbers, B.; Gerner, S.T.; Kloska, S.P.; Doerfler, A.; Schwab, S.; Huttner, H.B. Efficacy and safety of combined intraventricular fibrinolysis with lumbar drainage for prevention of permanent shunt dependency after intracerebral hemorrhage with severe ventricular involvement: A randomized trial and individual patient data meta-analysi. Ann. Neurol. 2017, 81, 93-103. [CrossRef]

213. Van der Steen, W.E.; Leemans, E.L.; van den Berg, R.; Roos, Y.; Marquering, H.A.; Verbaan, D.; Majoie, C. Radiological scales predicting delayed cerebral ischemia in subarachnoid hemorrhage: Systematic review and meta-analysis. Neuroradiology 2019, 61, 247-256. [CrossRef]

214. Van Norden, A.G.; van Dijk, G.W.; van Huizen, M.D.; Algra, A.; Rinkel, G.J. Interobserver agreement and predictive value for outcome of two rating scales for the amount of extravasated blood after aneurysmal subarachnoid haemorrhage. J. Neurol. 2006, 253, 1217-1220. [CrossRef]

215. Zijlstra, I.; Gathier, C.; Boers, A.; Marquering, H.; Slooter, A.; Velthuis, B.; Coert, B.; Verbaan, D.; Berg, R.V.D.; Rinkel, G.; et al. Association of Automatically Quantified Total Blood Volume after Aneurysmal Subarachnoid Hemorrhage with Delayed Cerebral Ischemia. Am. J. Neuroradiol. 2016, 37, 1588-1593. [CrossRef] [PubMed]

216. Jiménez-Roldán, L.; Alén, J.F.; Gómez, P.A.; Lobato, R.D.; Ramos, A.; Munarriz, P.M.; Lagares, A. Volumetric analysis of subarachnoid hemorrhage: Assessment of the reliability of two computerized methods and their comparison with other radiographic scales. J. Neurosurg. 2013, 118, 84-93. [CrossRef] [PubMed]

217. Ishihara, H.; Oka, F.; Kawano, R.; Shinoyama, M.; Nishimoto, T.; Kudomi, S.; Suzuki, M. Hounsfield Unit Value of Interpeduncular Cistern Hematomas Can Predict Symptomatic Vasospasm. Stroke 2020, 51, 143-148. [CrossRef] [PubMed]

218. Zhao, B.; Yang, H.; Zheng, K.; Li, Z.; Xiong, Y.; Tan, X.; Zhong, M. Preoperative and postoperative predictors of long-term outcome after endovascular treatment of poor-grade aneurysmal subarachnoid hemorrhage. J. Neurosurg. 2016, 126, 1764-1771. [CrossRef]

219. Liu, J.; Xiong, Y.; Zhong, M.; Yang, Y.; Guo, X.; Tan, X.; Zhao, B. Predicting Long-Term Outcomes After Poor-Grade Aneurysmal Subarachnoid Hemorrhage Using Decision Tree Modeling. Neurosurgery 2020, 87, 523-529. [CrossRef]

220. Kasuya, H.; Shimizu, T.; Takakura, K. Thrombin activity in CSF after SAH is correlated with the degree of SAH the persistence of subarachnoid clot and the development of vasospasm. Acta Neurochir. 1998, 140, 579-584. [CrossRef]

221. De Aguiar, P.H.; Barros, I.; Paiva, B.L.; Simm, R.F. Removal of clots in subarachnoid space could reduce the vasospasm after subarachnoid hemorrhage. Acta Neurochir. Suppl. 2013, 115, 91-93.

222. Roelz, R.; Coenen, V.A.; Scheiwe, C.; Niesen, W.D.; Egger, K.; Csok, I.; Kraeutle, R.; Jabbarli, R.; Urbach, H.; Reinacher, P.C. Stereotactic Catheter Ventriculocisternostomy for Clearance of Subarachnoid Hemorrhage: A Matched Cohort Study. Stroke 2017, 48, 2704-2709. [CrossRef]

223. Kawamoto, S.; Tsutsumi, K.; Yoshikawa, G.; Shinozaki, M.-H.; Yako, K.; Nagata, K.; Ueki, K. Effectiveness of the head-shaking method combined with cisternal irrigation with urokinase in preventing cerebral vasospasm after subarachnoid hemorrhage. J. Neurosurg. 2004, 100, 236-243. [CrossRef] [PubMed]

224. Kodama, N.; Sasaki, T.; Kawakami, M.; Sato, M.; Asari, J. Cisternal irrigation therapy with urokinase and ascorbic acid for prevention of vasospasm after aneurysmal subarachnoid hemorrhage: Outcome in 217 patients. Surg. Neurol. 2000, 53, 110-118. [CrossRef]

225. Kinouchi, H.; Ogasawara, K.; Shimizu, H.; Mizoi, K.; Yoshimoto, T. Prevention of Symptomatic Vasospasm After Aneurysmal Subarachnoid Hemorrhage by Intraoperative Cisternal Fibrinolysis Using Tissue-Type Plasminogen Activator Combined With Continuous Cisternal Drainage. Neurol. Med. Chir. 2004, 44, 569-577. [CrossRef]

226. Otawara, Y.; Ogasawara, K.; Kubo, Y.; Sasoh, M.; Ogawa, A. Effect of continuous cisternal cerebrospinal fluid drainage for patients with thin subarachnoid hemorrhage. Vasc. Heal. Risk Manag. 2007, 3, 401-404.

227. Della Pepa, G.M.; Scerrati, A.; Albanese, A.; Marchese, E.; Maira, G.; Sabatino, G. Protective effect of external ventricular drainage on cerebral vasospasm. A retrospective study on aneurysmal SAH treated endovascularly. Clin. Neurol. Neurosurg. 2014, 124, 97-101. [CrossRef] 
228. Maeda, Y.; Shirao, S.; Yoneda, H.; Ishihara, H.; Shinoyama, M.; Oka, F.; Sadahiro, H.; Ueda, K.; Sano, Y.; Kudomi, S.; et al. Comparison of lumbar drainage and external ventricular drainage for clearance of subarachnoid clots after Guglielmi detachable coil embolization for aneurysmal subarachnoid hemorrhage. Clin. Neurol. Neurosurg. 2013, 115, 965-970. [CrossRef] [PubMed]

229. Klimo, P., Jr.; Kestle, J.R.; MacDonald, J.D.; Schmidt, R.H. Marked reduction of cerebral vasospasm with lumbar drainage of cerebrospinal fluid after subarachnoid hemorrhage. J. Neurosurg. 2004, 100, 215-224. [CrossRef]

230. Borkar, S.A.; Singh, M.; Kale, S.S.; Suri, A.; Chandra, P.S.; Kumar, R.; Sharma, B.S.; Gaikwad, S.; Mahapatra, A.K. Spinal cerebrospinal fluid drainage for prevention of vasospasm in aneurysmal subarachnoid hemorrhage: A prospective, randomized controlled study. Asian J. Neurosurg. 2018, 13, 238-246. [CrossRef]

231. Panni, P.E.; Fugate, J.A.; Rabinstein, A.; Lanzino, G. Lumbar drainage and delayed cerebral ischemia in aneurysmal subarachnoid hemorrhage:a systematic review. J. Neurosurg. Sci. 2015, 61, 665-672.

232. Al-Tamimi, Y.Z.; Bhargava, D.; Feltbower, R.G.; Hall, G.; Goddard, A.J.; Quinn, A.C.; Ross, S.A. Lumbar drainage of cerebrospinal fluid after aneurysmal subarachnoid hemorrhage: A prospective, randomized, controlled trial (LUMAS). Stroke 2012, 43, 677-682. [CrossRef] [PubMed]

233. Khani, M.; Sass, L.R.; Sharp, M.K.; McCabe, A.R.; Verbick, L.M.Z.; Lad, S.P.; Martin, B.A. In vitro and numerical simulation of blood removal from cerebrospinal fluid: Comparison of lumbar drain to Neurapheresis therapy. Fluids Barriers CNS 2020, 17, 1-17. [CrossRef] [PubMed]

234. Blackburn, S.L.; Grande, A.W.; Swisher, C.B.; Hauck, E.F.; Jagadeesan, B.; Provencio, J.J. Prospective Trial of Cerebrospinal Fluid Filtration After Aneurysmal Subarachnoid Hemorrhage via Lumbar Catheter (PILLAR). Stroke 2019, 50, 2558-2561. [CrossRef] [PubMed] 